\title{
PRODUCTION OF LOW-DENSITY \\ POLY (4-METHYL-1-PENTENE) FOAM VIA \\ PHASE INVERSION FROM BINARY \\ SOLVENT/NONSOLVENT SYSTEMS
}

\author{
R. F. Simandl \\ D. N. Robinson
}

Materials Engineering Department

Development Division

W. L. Bolinger

W. E. Davis

Product Certification Division

Published: November 1991

Prepared by the

Oak Ridge Y-12 Plant

Oak Rudge, Tennessee 37831-8169

managed by

MARTIN MARIETTA ENERGY SYSTEMS, INC

for the

U.S. Department of Energy

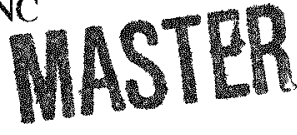

under contract DE-AC05-84OR21400 


\section{DISCLAIMER}

This report was prepared as an account of work sponsored by an agency of the United States Government. Neither the United States Government nor any agency Thereof, nor any of their employees, makes any warranty, express or implied, or assumes any legal liability or responsibility for the accuracy, completeness, or usefulness of any information, apparatus, product, or process disclosed, or represents that its use would not infringe privately owned rights. Reference herein to any specific commercial product, process, or service by trade name, trademark, manufacturer, or otherwise does not necessarily constitute or imply its endorsement, recommendation, or favoring by the United States Government or any agency thereof. The views and opinions of authors expressed herein do not necessarily state or reflect those of the United States Government or any agency thereof. 


\section{DISCLAIMER}

Portions of this document may be illegible in electronic image products. Images are produced from the best available original document. 


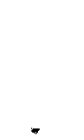




\section{CONTENTS}

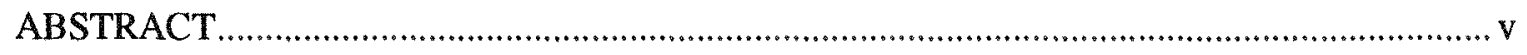

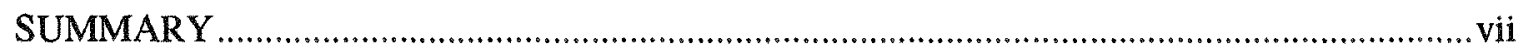

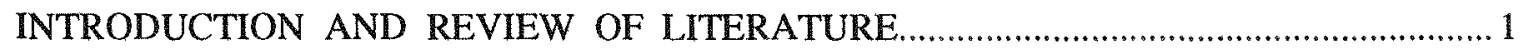

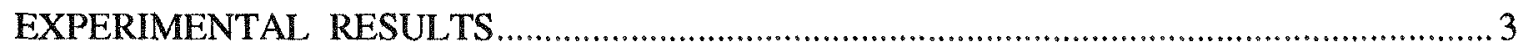

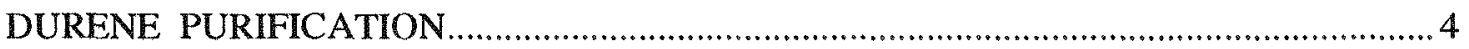

MOLECULAR WEIGHT DISTRIBUTION OF TPX® POLYMER ............................... 6

DIFFERENTIAL SCANNING CALORIMETRY CHARACTERIZATION $\ldots \ldots \ldots \ldots \ldots \ldots \ldots \ldots . . \ldots$

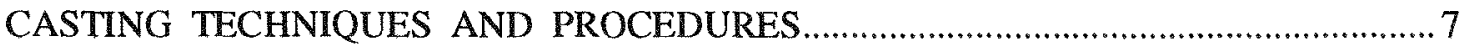

AIR-COOLED PYREX® TRAYS

STATISTICALLY DESIGNED CASTING STUDY ….............................................. 14

RESULTS OF STATISTICALLY DESIGNED EXPERIMENT .................................. 15

NONSOLVENTS THAT REDUCE DENSITY DIFFERENCES

BETWEEN SOLVENT AND GEL ................................................................... 18

DENSITY OF FOAM PRODUCT AS A FUNCTION OF ADDED

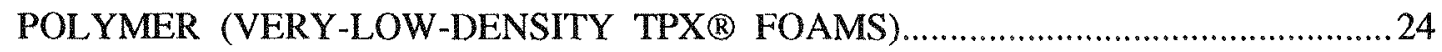

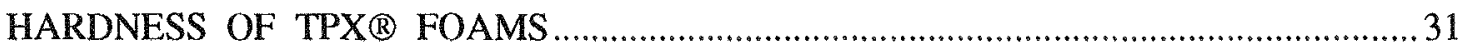

CONCLUSIONS

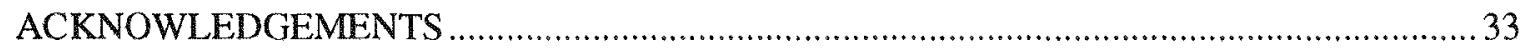

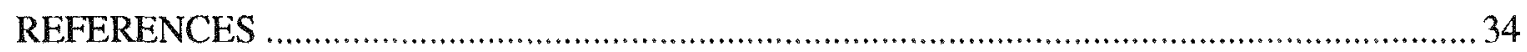

APPENDIX A: IMPURITIES FOUND IN DURENE/NAPHTHALENE/TPX® AS A FUNCTION OF HEATING CONDITIONS .................................. 37

APPENDIX B: OTHER INTFRESTING FOAM MORPHOLOGIES ..................................41 
. 


\begin{abstract}
Phase inversion from durene/naphthalene, durene/tmpdo, and durene/hexadecanol binary solvent/nonsolvent systems produced well interconnected, radiographically homogeneous, open-celled poly (4-methyl-1-pentene) or pmp foams. These foams ranged in density from 5 to $50 \mathrm{mg} / \mathrm{cm}^{3}$. Foam homogeneity and casting efficiency were dependent on casting scheme, durene quality, solvent-to-nonsolvent ratio, and quench temperature. Foam density tracked linearly with dissolved-polymer content. Homogeneous, ultralow-density $\left(5\right.$ to $\left.6 \mathrm{mg} / \mathrm{cm}^{3}\right)$ foams were produced by using a 49/51 durene/naphthalene solvent eutectic. Foam hardness or firmness tracked somewhat linearly with foam density. Foams with densities above $20 \mathrm{mg} / \mathrm{cm}^{3}$ were quite firm. Foams with densities below $6 \mathrm{mg} / \mathrm{cm}^{3}$ were too fragile to handle without damage.
\end{abstract}


. 


\section{SUMMARY}

The production of low-density poly (4-methyl-1-pentene) foam (pmp or TPX ${ }^{\circledR}$ foam) using phase inversion from binary solvent/nonsolvent systems has been studied extensively. (TPX® is a registered trademark of Mitsui Petrochemical Industries, Ltd., Tokyo, Japan.) In studies at the Oak Ridge Y-12 Plant, radiographically uniform foams ranging in density from 5.1 to $50 \mathrm{mg} / \mathrm{cm}^{3}$ were produced by using a durene/naphthalene solvent system. Solvent removal was accomplished by vacuum sublimation of the solvent blend. In addition to naphthalene, other nonsolvents, such as 2,2,4-trimethyl-1,3-pentanediol (tmpdo) and hexadecanol, have produced radiographically uniform foams. Solvent blends were removed from these foams by supercritical carbon dioxide $\left(\mathrm{CO}_{2}\right)$ extraction. Foam homogeneity and casting efficiency were dependent on casting scheme, durene quality, solvent-to-nonsolvent ratio, and quench temperature.

Two casting arrangements were explored and developed as part of this study. Casting and gelation at a rate of $1^{\circ} \mathrm{C} / \mathrm{min}$ in an insulated Pyrex ${ }^{\circledR}$ dish proved to be a much easier and faster technique and produced less waste than did casting and gelation at $0.2^{\circ} \mathrm{C} / \mathrm{min}$ in Teflon ${ }^{\circledR}$ cells in a hot oil bath. (Pyrex is a registered trademark of the Corning Glass Co, and Teflon is a registered trademark of the E. I. du Pont de Nemours Co., Wilmington, Delaware.) Efficiencies for the Pyrex ${ }^{\circledR}$ dish castings were equal to or better than those for castings made in the oil baths.

Casting to target density was dependent on the purity of the durene solvent. Density reproducibility and foam quality improved with increasing purity of the solvent. Foam density tracked linearly with the polymer content of the solvent melt. Homogeneous, ultralow-density ( 5 to $6 \mathrm{mg} / \mathrm{cm}^{3}$ ) pmp foams were produced by using a $49 / 51$ durene/naphthalene eutectic solvent blend. Foam hardness or firmness tracked less linearly with foam density. Pmp foams with densities greater than $20 \mathrm{mg} / \mathrm{cm}^{3}$ were quite firm, and those with densities less than $6 \mathrm{mg} / \mathrm{cm}^{3}$ were too fragile to handle. 


\section{INTRODUCTION AND REVIEW OF LITERATURE}

Production of low-density $\left(<200-\mathrm{mg} / \mathrm{cm}^{3}\right)$ polymer foams has received some attention in the literature over the last 15 years. Interest exists at Lawrence Livermore National Laboratory (LLNL), for example, in low-density polymer foams for use as targets in inertial-confinement fusion experiments. ${ }^{1}$ Microcellular foams made from polystyrene, cellulose acetate, and resorcinol-formaldehyde are discussed in Ref. 1. The resorcinol-formaldehyde foams are particularly impressive because of their small $(<0.1-\mu \mathrm{m})$ cell sizes.

In a U.S. patent, ${ }^{2}$ Castro gave a rather comprehensive account of methods for producing microporous, isotropic foams by liquid-liquid phase inversion. A rather exhaustive list of polymers and solvents and a description of the phase inversion process are included in the patent. In general, the patent discusses techniques for producing olefinic and oxidation polymer foams that exhibit pore sizes ranging from 0.1 to $5 \mu \mathrm{m}$. Castro indicated that, for each polymer/solvent combination, there exists a critical polymer concentration above which the polymer will phase invert and form a continuous phase around liquid solvent droplets. Below this concentration, the polymer will precipitate out as poorly connected aggregates, with the liquid solvent forming the interconnected continuous phase. In general. the Castro patent describes the useful range for producing polymer foams as 10 to $90 \%$ polymer, 90 to $10 \%$ solvent. In one case, low-molecular-weight polyethylene in diphenyl ether solvent, foams were produced by using as low as $7 \%$ polymer. This information was interpreted to mean that critical polymer concentrations implied by the patent typically exceed $7 \%$. The region of interest for pmp foams in this report includes 0.4 to $5 \mathrm{wt} \%$ polymer, a range much lower than the critical polymer concentration discussed in Ref. 2 .

The Castro patent also includes a discussion of the dependency of foam morphology on cooling rate. According to Castro, the cooling rate must be sufficiently fast that the temperature rapidly drops through the binodal liquid-liquid phase region into the spinodal region. The binodal region forms under conditions of thermal equilibrium and consists of two distinct layers, one layer consisting of polymer swollen with a soluble amount of liquid and a second layer consisting of a liquid solvent containing a soluble amount of polymer. Interestingly. Williams and Moore ${ }^{3}$ found that slow cooling rates were desirable for pmp in diisopropylbenzene. They found that rapid cooling or "deep quenching" resulted in the formation of polymer aggregates or segmented structures around polymer nuclei, with polymer-poor solvent forming the continuous phase. Williams and Moore explained that during rapid cooling the polymer in solution flows toward these nucleation points and that the residual polymer in solution is incapable of bridging the polymer-rich nucleation points. Cooling rates below $5^{\circ} \mathrm{C} / \mathrm{min}$ ensured that phase inversion occurred with the polymer as the continuous phase and thus produced well-connected pmp polymer webbing. Williams and Moore also found the same foam structure on both the solvent-rich and the polymer-rich side of the binodal. Polymer grade (molecular weight distribution) and solvent system were also listed as critical parameters. Williams and Moore claimed that foams were produced in the 25 to $830 \mathrm{mg} / \mathrm{cm}^{3}$ density range by using these "slow" $\left(<5^{\circ} \mathrm{C} / \mathrm{min}\right)$ cooling rates. They also claimed that the best foams were produced by using Mitsui high-molecular-weight DX-845 and that the worst were made by using medium-molecular-weight RT-18 Mitsui TPX®.

In a more recent report. ${ }^{4}$ Williams and Moore discussed changes in foam morphology as a function of parafin content in a paraffin/bibenzyl/pmp system and as a function of bibenzyl content in a bibenzyl/diisopropylbenzene/pmp system. 
In an LLNL report, ${ }^{5}$ Letts et al. discussed production of polyethylene foam using phase inversion from various solvents. These investigators found gel morphology to be sensitive to the dissolution temperature, cooling rate, molecular weight of polymer, solvent solubility parameters, and interfacial surface energy at the polymer/solvent boundary. The polymer of interest in the present report, poly (4-methyl-1-pentene), or pmp, is a predominantly isotatic, crystalline polyolefin. Crystallinity of the commercial pmp grades is typically $40 \%$ but can run as high as $65 \%{ }^{6}$ Seven grades of TPX ${ }^{\circledR}$ were obtained from Mitsui (U.S. office in White Plains, New York); each grade exhibited unique crystallinity, melt indices, and solubility. A density of $0.83 \mathrm{~g} / \mathrm{cm}^{3}$ makes pmp one of the lowest-density thermoplastics. Pmp is resistant to attack by many solvents, and its high crystallinity requires elevated temperatures for dissolution. Day ${ }^{6}$ discussed the various physical and chemical attributes of TPX®. Other information can be found in the Mitsui sales literature. Regarding crystalline forms of pmp, Charlet and Delmas ${ }^{7}$ reported that up to five different crystalline forms of pmp can be produced, depending on the solvent and the thermal history of the solution.

This report summarizes the findings of a study that focused on methods of producing microcellular poly (4-methyl-1-pentene) (TPX ${ }^{\circledR}$ or $\mathrm{pmp}$ ) foams by using liquid-liquid phase inversion from a suitable solvent/nonsolvent blend. The solvents chosen were solid waxes at room temperature that had high vapor pressures that allowed solvent removal via sublimation. In some cases, low-vapor-pressure nonsolvents produced good foams, and removal was accomplished by using the supercritical $\mathrm{CO}_{2}$ extraction. Use of solid solvents was explored because they gave early indications of producing lower-density foams than were obtainable by using liquid solvents. In addition, desired shapes could be readily machined out of wax bricks, and the solvents could be sublimed after the machining; thus, a near-net-shape foam object would be produced. 


\section{EXPERIMENTAL RESULTS}

Seven grades of TPX® were obtained from the U.S. office of Mitsui. Each grade exhibited unique crystallinity, melt indices, and solubility. Table 1 provides a listing of these grades, along with pertinent physical, mechanical, and thermal properties.

Table 1. Properties of Mitsui TPX(B)

\begin{tabular}{|c|c|c|c|c|c|c|c|}
\hline \multirow{2}{*}{ Properties $^{a}$} & \multicolumn{7}{|c|}{ Grade } \\
\hline & DX845 & RT18 & MX004 & MX002 & MX001 & DX810 & DX820 \\
\hline \multicolumn{8}{|l|}{ Physical: } \\
\hline Density, $\mathrm{g} / \mathrm{cm}^{3}$ & 0.835 & 0.835 & 0.840 & 0.835 & 0.835 & 0.833 & 0.833 \\
\hline $\begin{array}{l}\text { Melting point } \\
\quad \text { (ASTM D2117), }{ }^{\circ} \mathrm{C}\end{array}$ & 235 & 240 & 240 & 235 & 235 & 240 & 240 \\
\hline \multicolumn{8}{|l|}{$\begin{array}{l}\text { Onset of melting } \\
\text { (differential scanning } \\
\text { calorimetry), }{ }^{\circ} \mathrm{C}\end{array}$} \\
\hline $\mathrm{Y}-12$ value & & 228 & 221 & 207 & 214 & 232 & 232 \\
\hline Springborn value ${ }^{b}$ & 228 & 222 & 212 & 194 & 196 & 225 & 227 \\
\hline $\begin{array}{l}\text { Melt flow index } \\
\text { (ASTM D1238-82) }\end{array}$ & 8 & 26 & 26 & 22 & 26 & 70 & 180 \\
\hline \multicolumn{8}{|l|}{ Mechanical: } \\
\hline $\begin{array}{l}\text { Tensile strength } \\
\text { at yield, } \mathrm{kg} / \mathrm{cm}^{2}\end{array}$ & 260 & 235 & 200 & 150 & 140 & 260 & 230 \\
\hline $\begin{array}{l}\text { Tensile stress at break, } \\
\mathrm{kg} / \mathrm{cm}^{2}\end{array}$ & 260 & 175 & 175 & 160 & 150 & 200 & 175 \\
\hline $\begin{array}{l}\text { Elongation at break, } \\
\text { (ASTM D638), \% }\end{array}$ & 30 & 25 & 85 & 120 & 205 & 10 & 20 \\
\hline \multicolumn{8}{|l|}{ Thermal: } \\
\hline $\begin{array}{l}\text { Vicat softening point } \\
\text { (ASTM D1525), }{ }^{\circ} \mathrm{C}\end{array}$ & 185 & 173 & 160 & 145 & 147 & 180 & 173 \\
\hline $\begin{array}{l}\text { Thermal deformation } \\
\text { temperature } \\
\text { (ASTM D648), }{ }^{\circ} \mathrm{C}\end{array}$ & 100 & 90 & 85 & 80 & 80 & 100 & 100 \\
\hline
\end{tabular}

${ }^{3}$ Data supplied by Mitsui.

${ }^{\mathrm{b}}$ Springborn Testing Institute, Inc., Enfield, Connecticut.

Though rather insoluble in most solvents at room temperature, pmp is quite soluble in a number of nonpolar solvents at elevated temperatures. Certain of the aromatic solvents, such as toluene and xylene, attack pmp at temperatures less than $100^{\circ} \mathrm{C}$. In the way of comparison, durene $\left(1,2,4,5\right.$,-tetramethylbenzene) begins to attack RT-18 TPX(B) pellets at $\sim 110^{\circ} \mathrm{C}$. For reasons mentioned previously, solid solvents were expected to be desirable for this study, and 
durene was chosen as the solvent. One of the unanticipated problems associated with this decision was the extreme sensitivity of foam quality to the presence of the liquid impurities, primarily isodurene (1,2,3,5-tetramethylbenzene) and pseudocumene (1,2,4-trimethylbenzene). The importance of a nonsolvent to phase inversion was recognized early in this study. When a solid solvent is employed, phase inversion must occur at temperatures above the freezing temperature of the solvent. Pmp has very good solubility in durene at elevated temperatures but will not phase invert until the durene crystllizes. At durene's freezing temperature $\left(79.2^{\circ} \mathrm{C}\right)$, the crystallization of durene forces rejection of the pmp in a random fashion along intergranular boundaries. The result is an inhomogeneous, poorly connected gel. The presence of a poor solvent or nonsolvent, such as naphthalene, raises the temperature of onset of phase inversion above the freezing temperature of the solvent. For example, in the case of Mitsui RT-18 TPX® polymer in $60 \mathrm{wt} \%$ durene $/ 40 \mathrm{wt} \%$ naphthalene, gelation began and an isotherm was observed at $112^{\circ} \mathrm{C}$. In the case of Mitsui MX001 TPX® polymer in the same binary solvent/nonsolvent system, gelation began and an isotherm was observed at $105^{\circ} \mathrm{C}$. By adjustment of the ratio of nonsolvent to solvent, it was actually possible to tailor the gel temperature to whatever was desired. This degree of freedom was restricted, however, by the target density of the foam, which limited the range of useful solvent-to-nonsolvent ratios. As discussed later, low-density TPX $®$ foams $\left(<25 \mathrm{mg} / \mathrm{cm}^{3}\right)$ required the use of near-eutectic durene/naphthalene solvent blends, whereas densities above this required the higher solvency of the durene; hence, the 70-30 durene-naphthalene ratio was preferred.

\section{DURENE PURIFICATION}

Although the observation was never formally verified with a statistically designed experiment, the quality of TPX ${ }^{\circledR}$ foam appeared to track with the quality of the durene solvent. Foam quality in this study was equated to uniform optical density of radiographs of the foam. Liquid-solvent impurities in the durene appeared to play havoc with the quality of TPX® foam. (Pmp foam collapses to varying degrees when droplets of different solvents are applied to the surface.) Moreover, foam quality invariably improved whenever the durene was purified. Although solid solvents were more likely to be rejected by the polymer during phase inversion, it was reasoned that liquid solvents were more soluble in the polymer webbing, thereby plasticizing the webbing. Upon vaccuum removal of the solvents, the webbing would experience shrinkage and hence densification as the dissolved solvent was removed. Furthermore, vapor phase attack by the liquid-solvent fraction would tend to densify the foam in an inhomogeneous fashion during sublimation, leaving regions of low density in the center and along corner-to-corner diagonals of foam parts.

Considerable effort was expended, therefore, to develop a method of purifying durene to eliminate the liquid impurity. (Naphthalene always tested very high in purity, and consequently no effort was made to further purify it.) An inexpensive, $>95 \%$ technical grade of durene was purchased; as received, it varied greatly in purity. Visually, the durene appeared anywhere from white to very brown. In one drum alone, durene purity varied from the top of the drum to the bottom. Typcially, the higher-purity durene was found at the top of the drum because the liquid fractions separated and flowed to the bottom of the drum. These fractions often carried oxidized, discolored fractions along with them to the bottom of the drum. Durene is a high-octane-number by-product of petroleum refining. Because of its waxlike nature, it interferes with proper carburization or fuel injection and is thus an undesirable component of gasoline. Numerous patents exist which address removal of durene from gasoline. ${ }^{8-12}$ 
Table 2 gives typical analyses for the technical-grade durene. This table is included to give only a rough idea of the impurities found in technical-grade durene. Analysis will vary with the source of durene.

Table 2. Analysis of technical-grade durene as determined by gas chromatography-mass spectrometry

\begin{tabular}{lcccc}
\hline & $\begin{array}{c}\text { Durene } \\
(\text { wt } \%)\end{array}$ & $\begin{array}{c}\text { Isodurene } \\
(\text { wt } \%)\end{array}$ & $\begin{array}{c}1,2,4 \text {-trimethyl- } \\
\text { benzene }\end{array}$ & $\begin{array}{c}\text { Two Isomers of } \\
\text { trimethyl-benzaldehyde }\end{array}$ \\
\hline $\begin{array}{c}\text { Durene from top } \\
\text { of drum }\end{array}$ & 99 & 0.8 & $0.2 \mathrm{wt} \%$ & $<250 \mathrm{ppm}$ \\
$\begin{array}{c}\text { Wet" durene from } \\
\text { bottom of drum }\end{array}$ & 98 & 1.0 & $<500 \mathrm{ppm}$ & $0.7 \%$ \\
\hline
\end{tabular}

Table 3 lists impurities found in a brown liquid fraction drained from the bottom of a drum of discolored technical-grade durene. These impurities were identified by gas chromatography-mass spectrometry (GC-MS). Physical properties are included as additional information and for convenience of the reader.

Table 3. Gas chromatography-mass spectrometry analysis of the brown liquid fraction drained from a drum of discolored durene

\begin{tabular}{|c|c|c|c|c|c|}
\hline $\begin{array}{l}\text { Chemical name } \\
\text { of impurity }\end{array}$ & Synonym & $\begin{array}{l}\text { Molecular } \\
\text { weight }\end{array}$ & $\begin{array}{l}\text { Melting } \\
\text { temp. }\left({ }^{\circ} \mathrm{C}\right)\end{array}$ & $\begin{array}{l}\text { Boiling } \\
\text { temp. ( }\end{array}$ & $\begin{array}{l}\text { Density } \\
\left(\mathrm{g} / \mathrm{cm}^{3}\right)\end{array}$ \\
\hline 1,3,5-Trimethylbenzene & Mesitylene & 120.2 & -44.7 & 164.7 & 0.8652 \\
\hline 1,2,4-Trimethylbenzene & Pseudocumene & 120.2 & -43.8 & 169.4 & 0.8758 \\
\hline 1,2,3-Trimethylbenzene & Hemimellitene & 120.2 & -25.4 & 176.1 & 0.8944 \\
\hline 1-Isopropyl-3-methylbenzene & $m$-Cymene & 134.22 & -63.8 & 175.1 & 0.8610 \\
\hline 1-Isopropyl-4-methylbenzene & $p$-Cymene & 134.22 & -67.9 & 177.1 & 0.8573 \\
\hline 1-Isopropyl-2-methylbenzene & o-Cymene & 134.22 & -71.5 & 178.2 & 0.8766 \\
\hline 1,2,4,5-Tetramethylbenzene & Durene & 134.22 & +79.2 & 196.8 & 0.8380 \\
\hline 1,2,3,5-Tetramethylbenzene & Isodurene & 134.22 & -23.7 & 198.0 & 0.8903 \\
\hline 1,2,3,4-Tetramethylbenzene & Prehnitene & 134.22 & -6.3 & 205.0 & 0.9052 \\
\hline 3,4,5-Trimethylbenzaldehyde & & 148.21 & $a$ & $\alpha$ & $a$ \\
\hline 2,4,6-Trimethylbenzaldehyde & Mesitylaldehyde & 148.21 & 14.0 & 238.0 & 1.0050 \\
\hline 4-Isopropylaldehyde & Cumaldehyde & 148.21 & & 235.0 & 0.9755 \\
\hline \multicolumn{6}{|l|}{$\begin{array}{l}\text { Unidentified mol. wt } \\
150 \text { species }^{a}\end{array}$} \\
\hline Durene dimer ${ }^{a}$ & & & & & \\
\hline
\end{tabular}

${ }^{a}$ No references found. 
After a two-stage recrystallization from 1,1,2-1,2,2-trichlorotrifluoroethane (Freon ( 113), the purified durene analyzed typically $<300 \mathrm{ppm}$ impurities. (Freon is a registered tradename of the E. I. du Pont de Nemours Co., Wilmington, Delaware.) The purified durene retained low levels of Freon $(\mathbb{B} 113(500 \mathrm{ppm})$, but this was driven off later when durene was heated to dissolve the pmp.

\section{MOLECULAR WEIGHT DISTRIBUTION OF TPX( POLYMER}

To better characterize our starting materials, we thought it desirable to determine the molecular weight distribution of various grades of pmp. Since pmp dissolves only at elevated temperatures, the Y-12 Plant contracted with both Springborn Testing Institute (at Enfield, Connecticut) and Allied-Signal Aerospace, Kansas City Division (at Kansas City, Missouri) to perform high-temperature gel permeation chromatography (GPC) on various grades of pmp. (At that time, Y-12 did not have the GPC capability.) Analyses were run at 140 and $145^{\circ} \mathrm{C}$ in $0.2-$ and $0.1-\mathrm{mg} / \mathrm{L}$ solutions, respectively, with 1,2,4-trichlorobenzene as the solvent. Since polymer degradation at high temperatures is a problem, Springborn used 4,4-thiobis-(6-tertiary butyl meta cresol) in $0.15 \mathrm{wt} \%$ concentrations as an antioxidant. Allied-Signal used Irganox ${ }^{\circledR} 1010$ at the level of $1 \mathrm{~g} / 4 \mathrm{~L}$. (Irganox ${ }^{\circledR}$ is a registered trademark of the Ciba-Geigy Corp., Hawthorne, New York.) Thermal degradation of polyolefins is discussed by Grinshpun ${ }^{13}$ and by Fuller.

Figure 1 shows the results of the GPC characterizations. The analyses are grouped according to grades of Mitsui TPX®. A pair of clusters is shown for each grade of TPX® except for DX845, the high-molecular-weight polymer. The center bar in each cluster represents the weight average molecular weight determined for each grade. The left and right bars represent minus one standard deviation and plus one standard deviation, respectively. The left cluster of each pair of clusters gives the molecular weight distribution as determined by Springborn, and the right cluster represents the distribution determined by Allied-Signal. The numbers over each cluster represent the polydispersity ${ }^{14}$ of the distribution. Agreement between results from both laboratories is good, varying $<20 \%$ in the worst case.

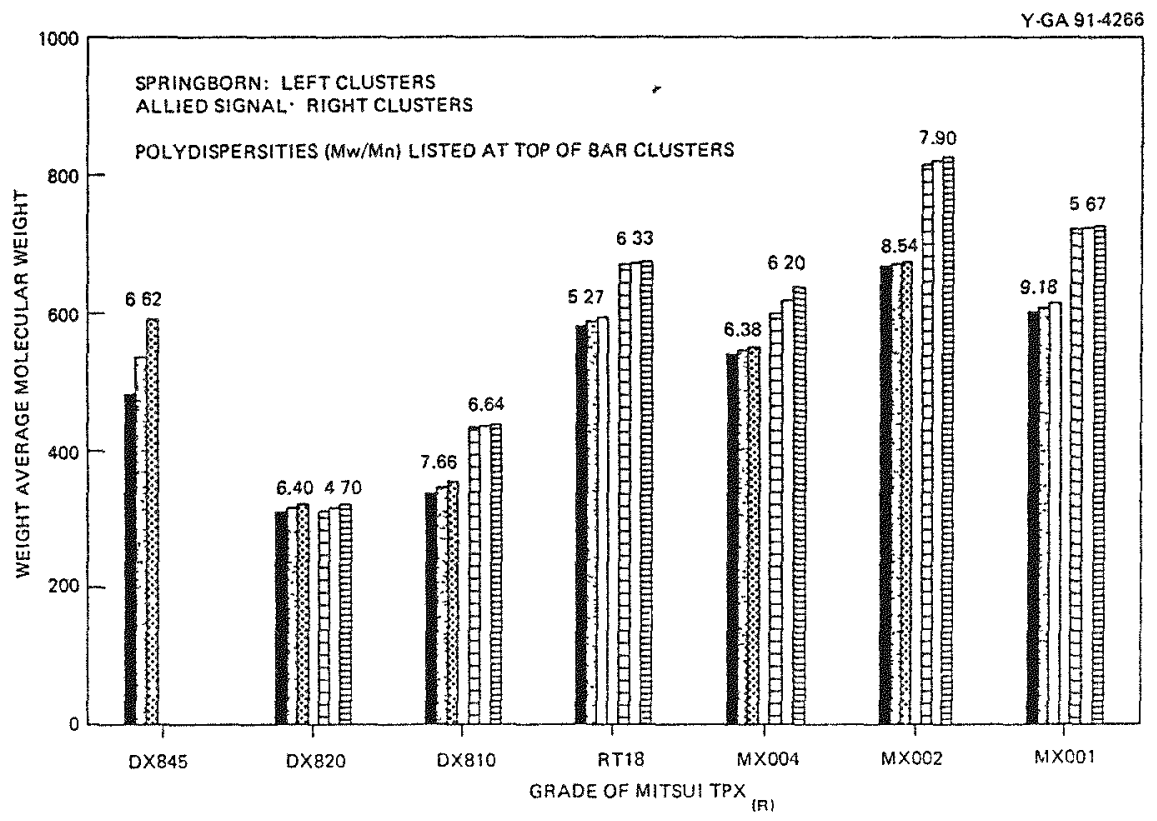

Fig. 1. Weight average molecular weight as a function of grade of Mitsui TPX ${ }^{\circledR}$. 


\section{DIFFERENTIAL SCANNING CALORIMETRY CHARACTERIZATION}

The various grades of TPX(B) were further characterized by Springborn Testing Institute and at the Y-12 Plant by differential scanning calorimetry (DSC). The resulting melting point data are listed along with the manufacturer-supplied data in Table 1.

\section{CASTING TECHNIQUES AND PROCEDURES}

Casting cells "evolved" along with the experimental pmp foam program. At first, casting cells were machined from aluminum blocks and used steel faceplates that were bolted to the cells. Eventually, the benefits of unidirectional cooling were recognized, and an optimal cell was designed that incorporated well-insulated slow cooling from all faces except one. Figure 2 shows such a cell, disassembled. This cell consisted of a $7 \times 19 \times 28 \mathrm{~cm}$ Teflon $B$ block from which a $5.1 \times 17.1 \times 22.9 \mathrm{~cm}$ cavity was machined. A 0.32 -cm-thick stainless steel plate is shown, and this was normally bolted to the Teflon $(B)$ cell during casting. The casting cell is shown assembled in Fig. 3. A double layer of aluminum foil (25 $\mu \mathrm{m}$ thick) is shown sandwiched between the steel plate and the Teflon $(8)$ cell. The purpose of the aluminum foil was to follow the wax casting in toward the steel faceplate during solidification of the wax, when the wax normally experienced $30 \%$ volume shrinkage. This prevented the wax from sticking to the Teflon $($ cell and from tearing itself apart internally. The steel faceplate served two purposes: it provided single-surface, unidirectional cooling, and it gave the wax brick one flat face that was desirable for machining. An O-ring or a flat gasket was unnecessary, since the Teflon $\otimes$ crept slightly at the casting temperature $\left(150^{\circ} \mathrm{C}\right)$ under the pressure provided by the bolts and thereby formed its own seal. During casting, an assembled cell was immersed in 11 to $12 \mathrm{~L}$ of either mineral oil or high-flash-point silicone oil at $150^{\circ} \mathrm{C}$ in an insulated bath. This arrangement is shown in Fig. 4. The desired amount of TPX® polymer was dissolved in a given durene/naphthalene solvent blend and heated to $150^{\circ} \mathrm{C}$ in $3-\mathrm{L}$ Pyrex $($ b beakers that were covered with aluminum foil. (Later in the experiment, covered, purged, stainless steel "teapots" were used. These teapots served to exclude light and air during the dissolution process. They also facilitated pouring of the melt. Once the polymer was thoroughly dissolved, the melt was poured into the hot casting cells in the oil bath through a 325 -mesh $(50-\mu \mathrm{m}$ openings) stainless steel screen to filter out any visible nucleating particulate. The cells were covered with porous Fiberfrax $(B)$ insulation. (Fiberfrax $(\mathbb{R})$ is a registered trademark of the Carborundum Corporation, Niagara Falls, New York.) In addition to offering thermal insulation, the porous insulation wicked up condensing solvent and kept it from dripping back into the melt and destroying uniform gel structure.

The entire oil bath was covered with thermal insulation, and the entire setup provided highly uniform thermal conditions. Cooling rates through the gel stage typically ran between 0.15 and $0.2^{\circ} \mathrm{C} / \mathrm{min}$. Once the oil bath temperature reached 80 to $85^{\circ} \mathrm{C}$, gelation was complete, and the casting cell was removed and placed in ice water in a pressure vessel. The ice water quenched the casting and contributed to the formation of small wax crystals. Eutectic blends of durene and naphthalene likewise contributed to small wax crystals. Pressure was necessary to press the casting together and accommodate for the shrinkage experienced during solidification of the wax. A pressure of 40 psig was sufficient. An abundance of internal voids resulted when pressure was not used. 


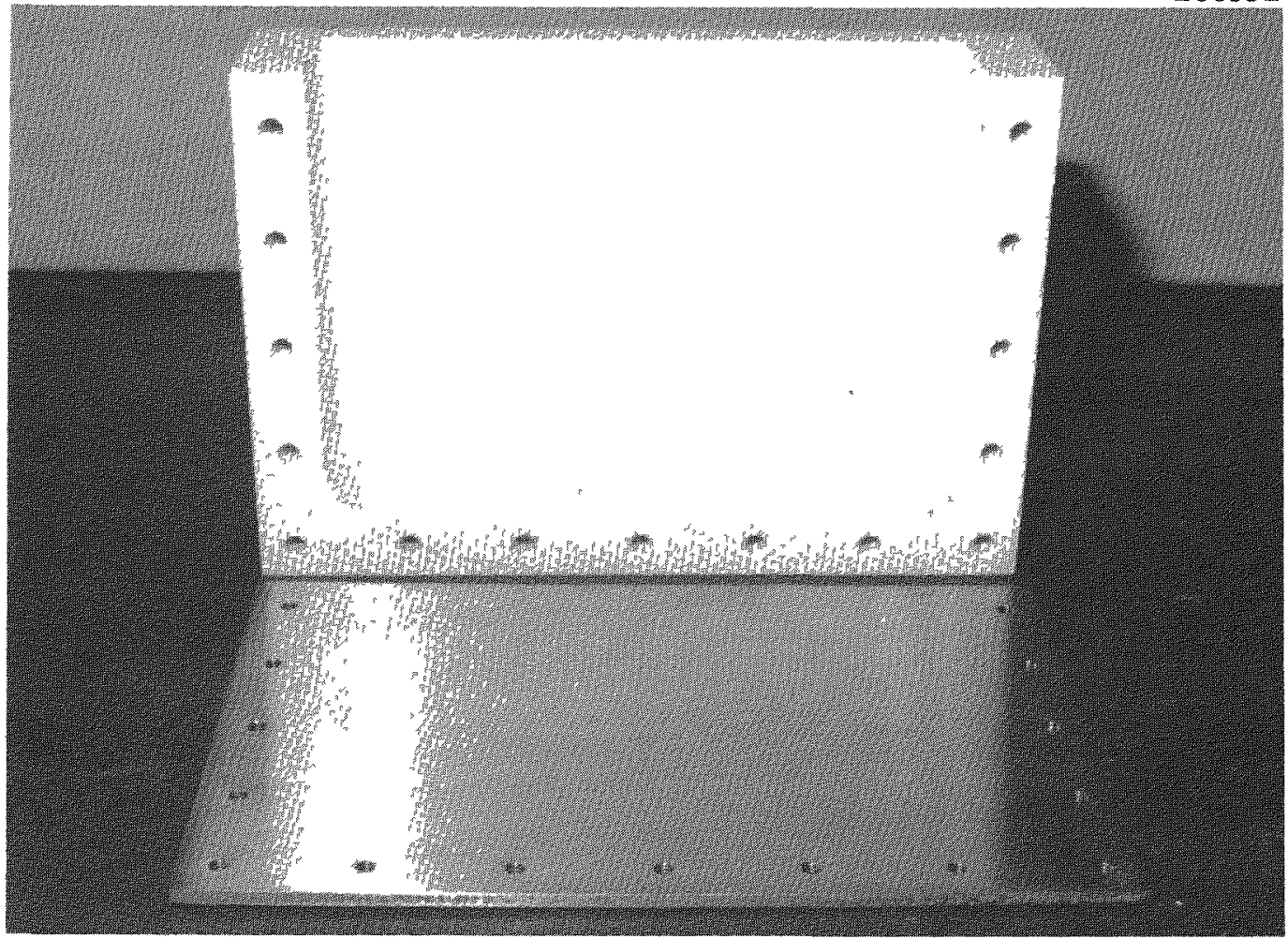

Fig. 2. Disassembled Teflon $®$ casting cell with stainless steel faceplate.

266351

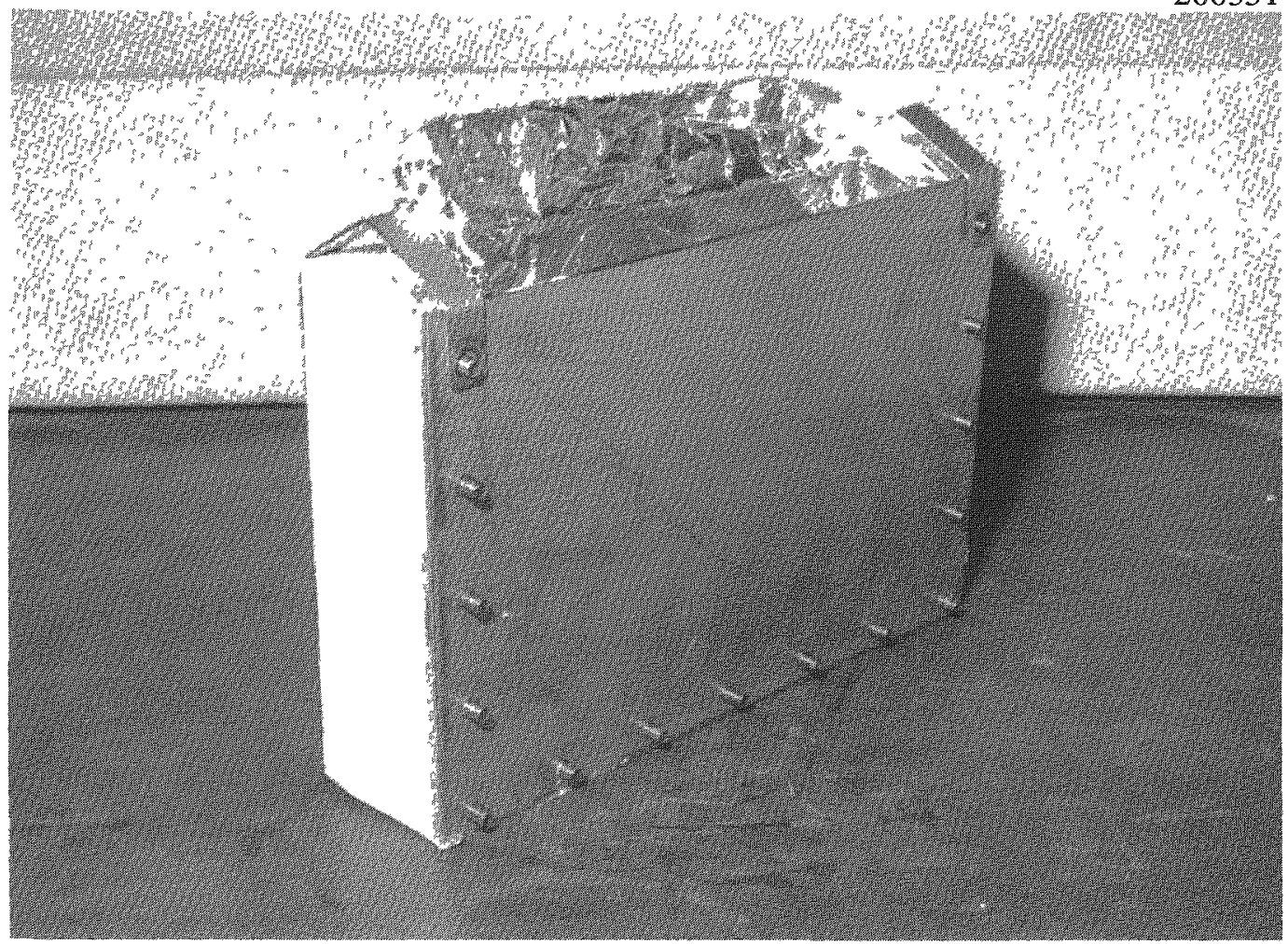

Fig. 3. Assembled Teflon ${ }^{\circledR}$ casting cell. 


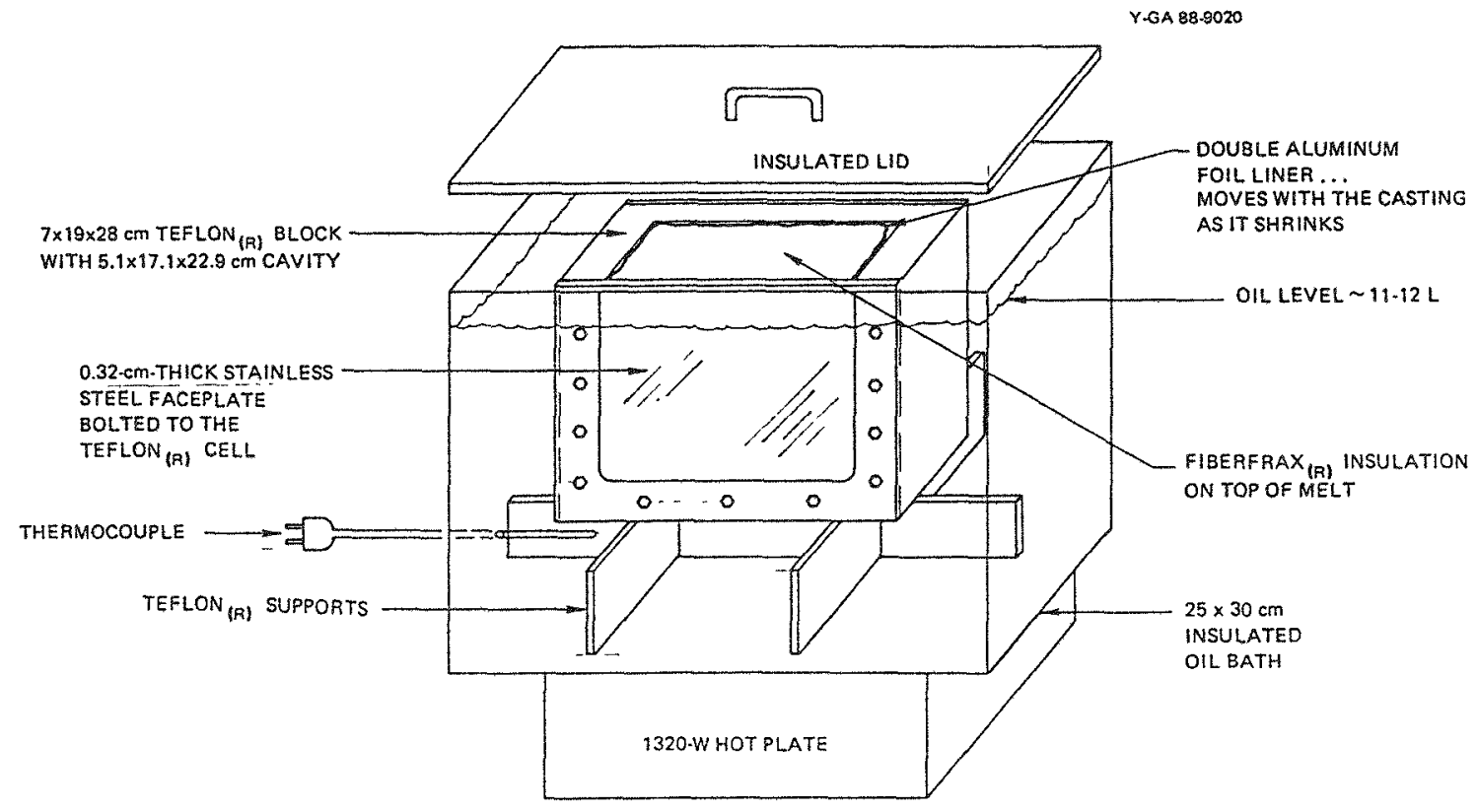

Fig. 4. Diagram of Teflon ${ }^{\circledR}$ casting cell in oil bath.

Figure 5 shows the resulting wax brick along with wax pieces machined from a similar brick. Approximately one-half of the brick was homogeneous enough to make radiographically uniform foam; this was the half nearest the steel faceplate. The other half, the one nearest the aluminum foil, accommodated most of the density inhomogeneities resulting from shrinkage and was discarded. One interesting feature resulting from such shrinkage was a polymer density gradient. A high-density zone (HDZ) of polymer was found nearest the aluminum foil side of the casting and is explained by Fig. 6 . The location and range of the high-density zone varied with the difference in cooling rates between the faceplate and the casting cell. In other words, the use of a thermally insulating material (such as Teflon(B) for the casting cell moved the high-density zone out of the useful cutting zone. A thermally conducting aluminum cell was detrimental in the sense that it spread the inhomogeneous high-density zone into the cutting zone. Fig. 7, a radiograph of a cross section of a thick section of pmp foam, shows the high-density zone near the aluminum foil side of the casting. The solvent solidified at the steel faceplate first and then formed a crust at the aluminum foil interface. Liquid solvent in the center of the casting wicked out toward the cooler regions of the casting as shrinking of wax accompanied solidification in those regions. Pressure behind the casting tended to flatten the cells in the warm center of the casting, giving it a high-density profile. Figure 8 shows a scanning electron micrograph (SEM) of the high-density region of a pmp foam sample. Notice the flattened cells compared with the more regularly shaped cells shown in Fig. 9, which shows a SEM micrograph of a typical sample of pmp foam cut from the region nearest the steel faceplate.

After machining, solvent was removed by sublimation in a vacuum oven. Samples were weighted down and kept flat in the ovens by a stainless steel screen that was stretched over and welded to a steel frame. A cold trap, operated at -40 to $-50^{\circ} \mathrm{C}$, captured the solvent and kept it from fouling the vacuum pump. 


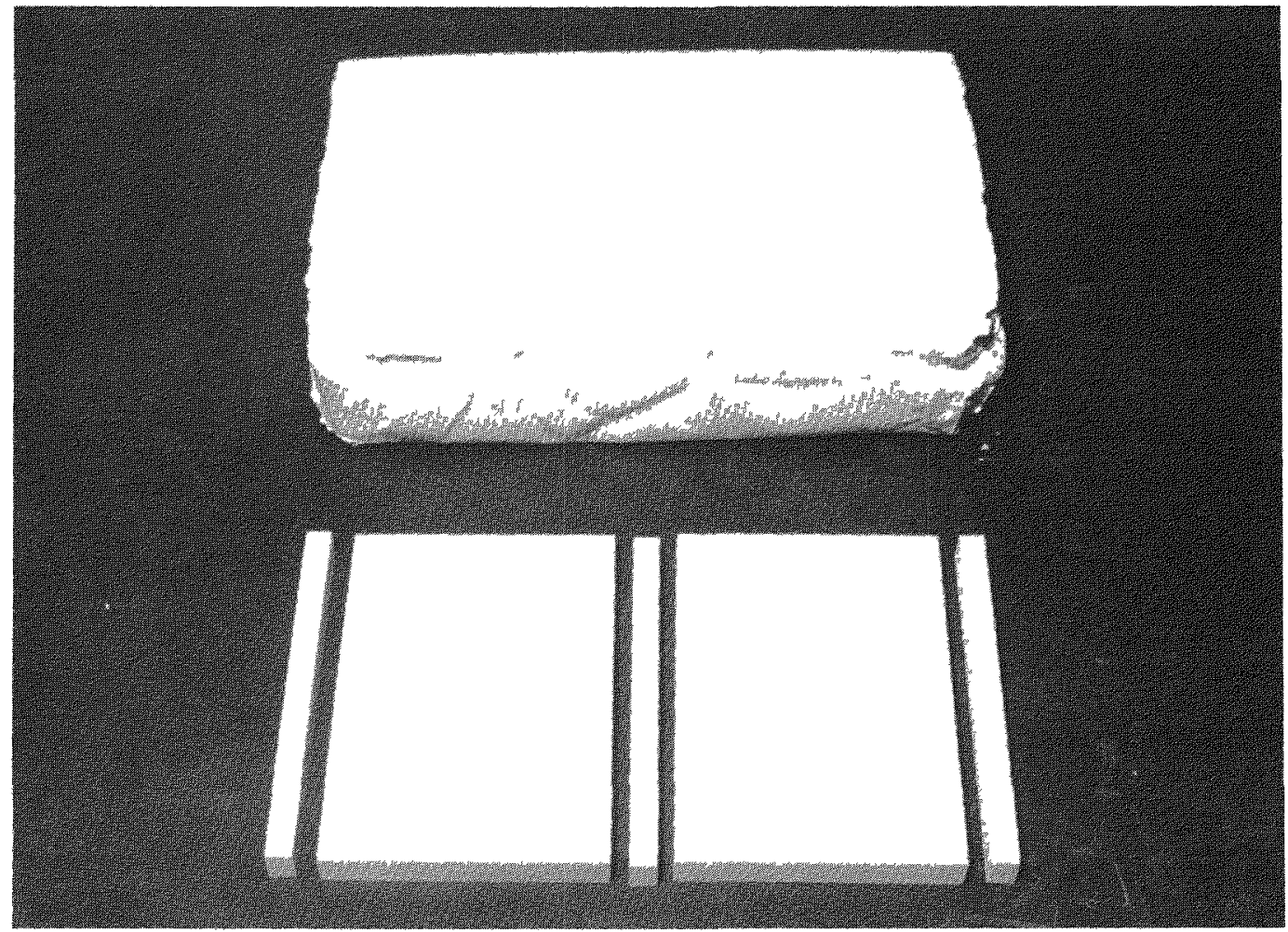

Fig. 5. Wax brick (top) and machined wax pieces (bottom).

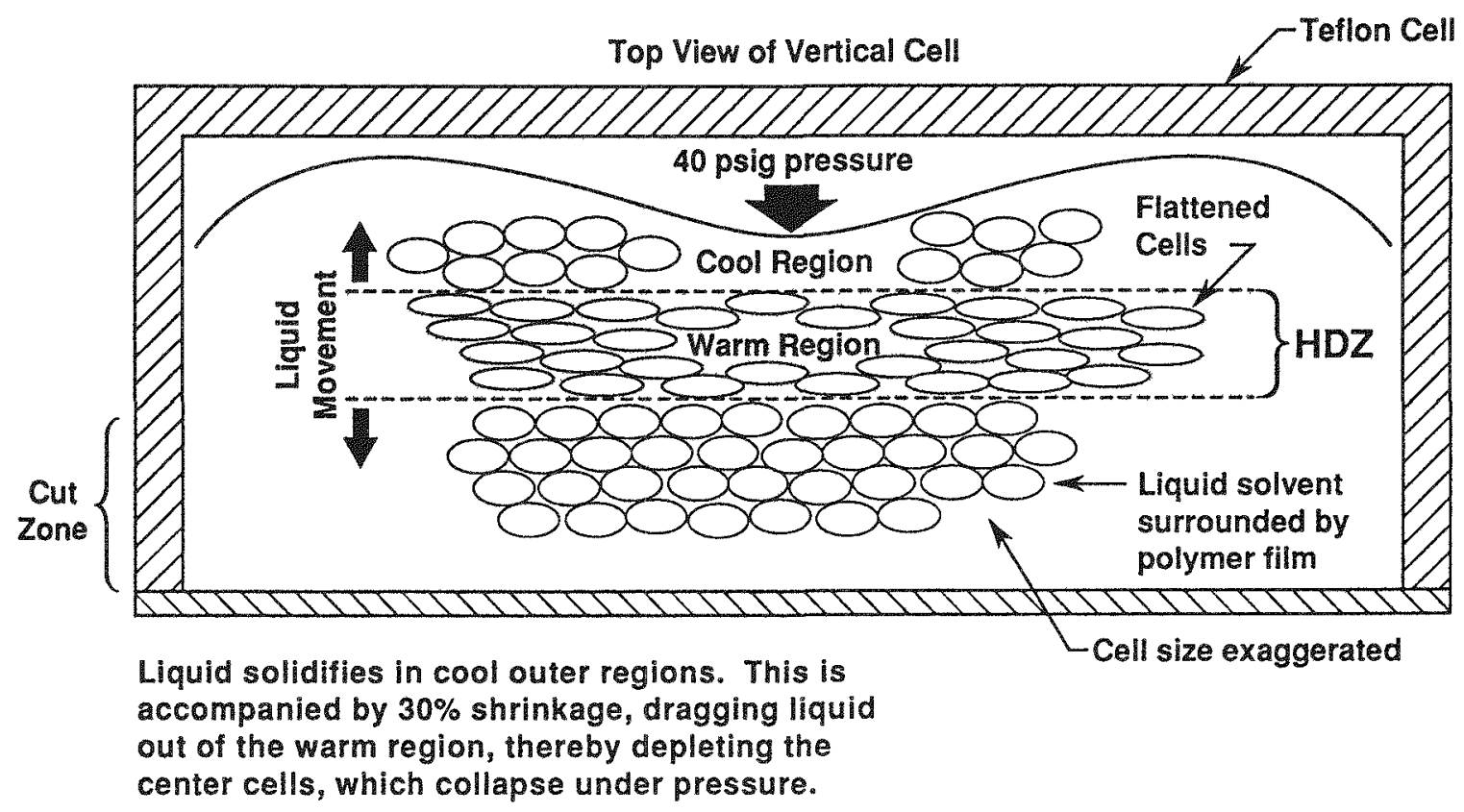

Fig. 6. Formation of polymer high-density zone near aluminum foil side of casting. 


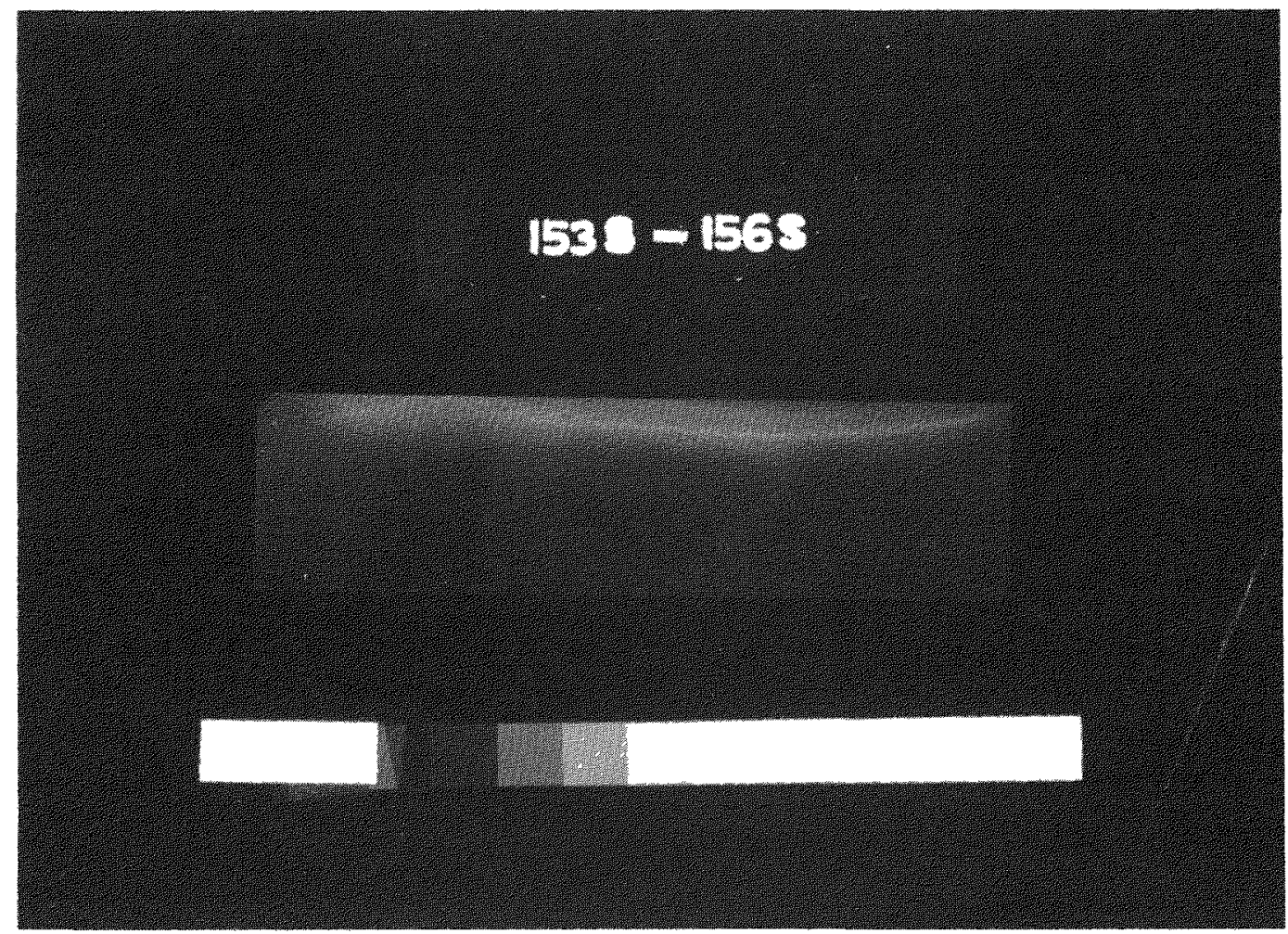
zone.

Fig. 7. Radiograph of thick cross of pmp foam, showing the high-density

\section{AIR-COOLED PYREX® TRAYS}

At one point during the experimental program, gelation was observed in glass beakers for the purpose of making some fundamental observations of the gelation process. These observations were scaled up to larger Pyrex ${ }^{\circledR}$ trays, and it was observed that fairly uniform gels could be produced by using these large trays and casting in a horizontal configuration. Interest began to focus on this technique because cell preparation and cleanup were much less difficult than for the Teflon(B) cells in oil baths. Castings were made into clean $26.5 \times 37.5 \times 5.7 \mathrm{~cm}$ Pyrex $\left({ }_{1}\right.$ trays that were preheated to $150^{\circ} \mathrm{C}$ in an oven. Pmp polymer was dissolved as before, and the $150^{\circ} \mathrm{C}$ melt was poured into the hot trays through a 325-mesh stainless steel screen. The entire tray was covered with a $1-\mathrm{cm}$ thickness of Fiberfrax ${ }^{\circledR}$ insulation, which served as thermal insulation, reduced evaporative losses, and eliminated solvent refluxing and accompanying damage to the gel structure. Cooling rates through the gel phase generally ran higher than those for the Teflon $(B)$ cell configuration, typically 1 to $2^{\circ} \mathrm{C} / \mathrm{min}$.

Like casting in the Teflon $\circledast$ cells, gelation was taken to completion in the Pyrex $®$ trays before the solvent was quenched. Once gelation was complete, the trays were moved to a horizontal chill plate that was mounted in a pressure vessel. Temperature of the chill plate was maintained with the use of circulating ethylene glycol solution pumped from a refrigerated bath. Chill plate temperatures as low as $-25^{\circ} \mathrm{C}$ could be maintained with this arrangement. Castings were put under 40 psig air pressure during solvent solidification on the chill plate in order to eliminate void formation. Initial castings done in the Pyrex ${ }^{\circledR}$ trays produced excellent foams. A statistical study was planned to compare the two casting arrangements as well as other casting parameters. 


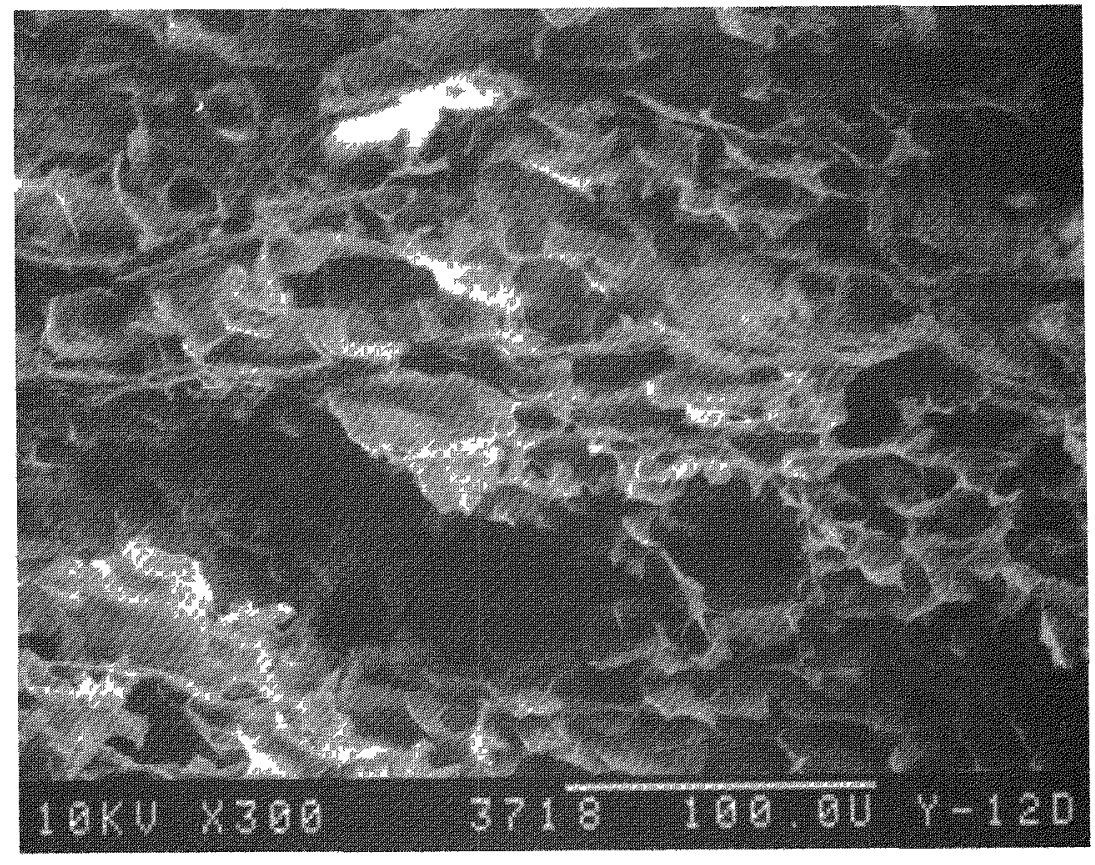

(a)

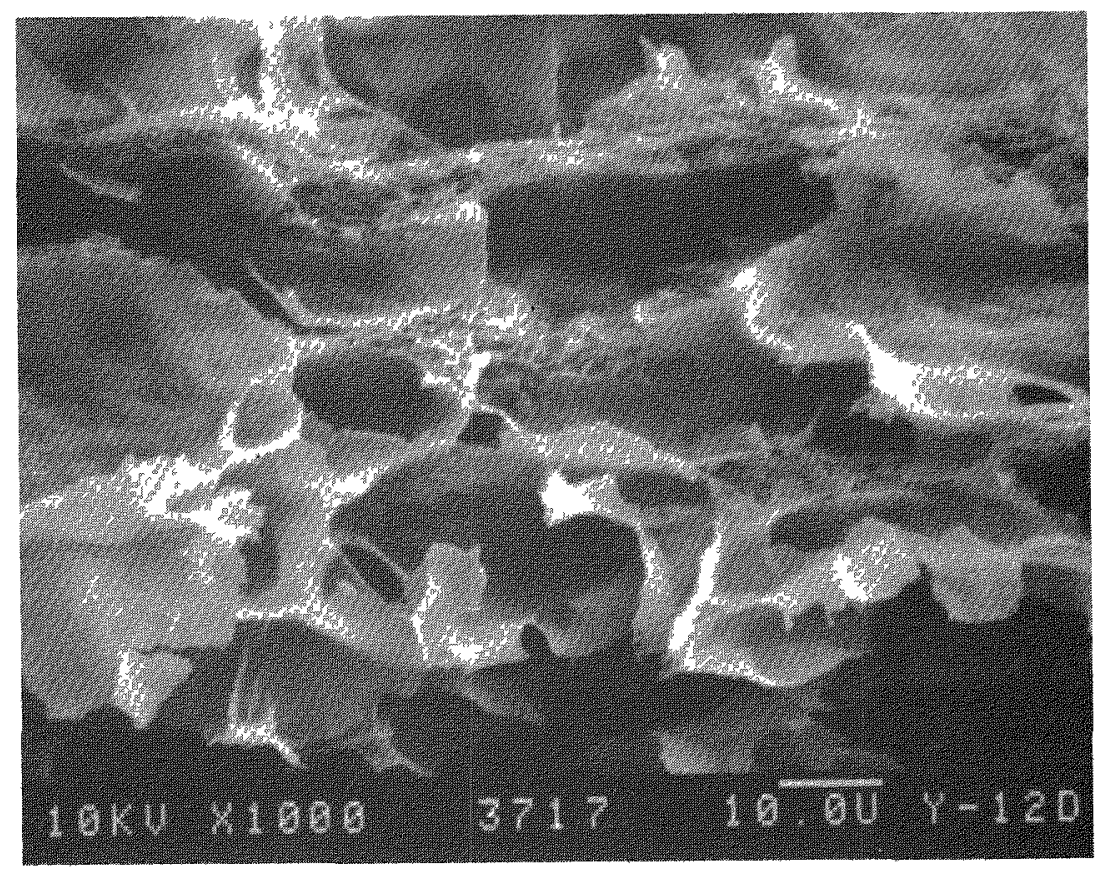

(b)

Fig. 8. SEM photomicrographs of the high-density zone in a $30-\mathrm{mg} / \mathrm{cm}^{3}$ TPX foam sample: (a) 300x; (b) 1000×. 


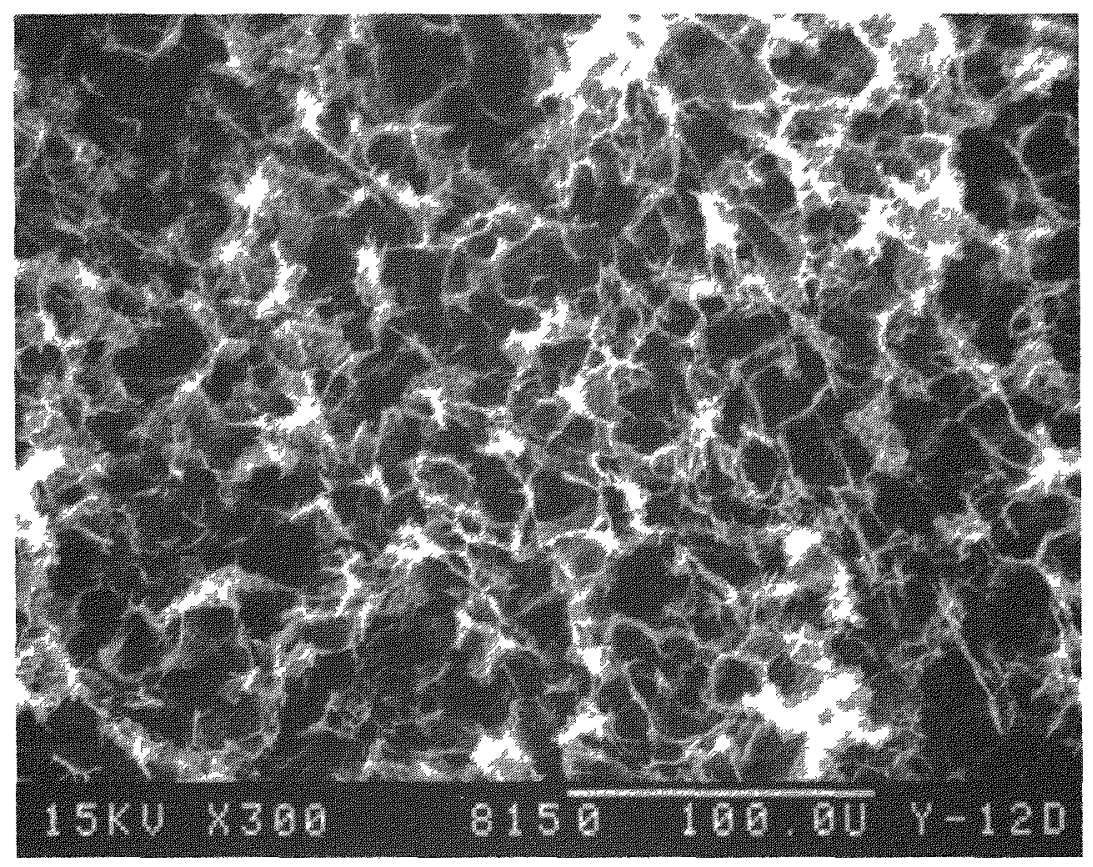

(a)

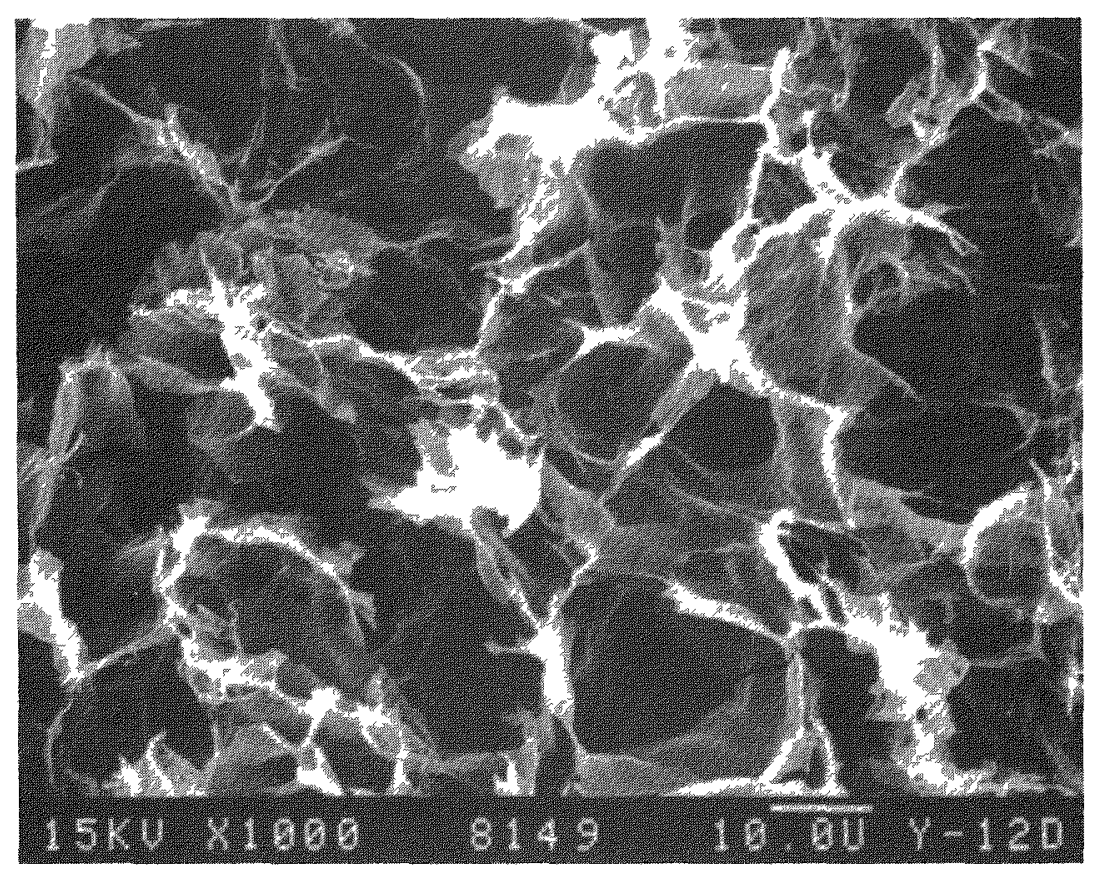

(b)

Fig. 9. SEM photomicrographs of the homogeneous region below the high-density zone in a 30-mg/cm ${ }^{3}$ TPX® foam sample: (a) $300 \times$, (b) $1000 \times$. 


\section{STATISTICALLY DESIGNED CASTING STUDY}

After several years experience was gained in producing pmp foam, we began to identify the casting parameters that appeared to have an impact on the radiographic quality of the pmp foam product. Experience and intuition were used to cull a manageable number of parameters for further testing and statistical verification. The following parameters were chosen: solvent-to-nonsolvent ratio, durene quality, cover gas, and casting configuration (which included gel rate). Quench temperature was partially explored.

The solvent-to-nonsolvent ratio presented a unique problem. For high-density foams, a high ratio was required simply to dissolve the higher concentration of pmp. Similarly, for high-molecular-weight pmp, a higher concentration of durene was required. The higher the ratio of solvent to nonsolvent, the farther one moves away from the durene/naphthalene eutectic (49 wt $\%$ durene/51 wt \% naphthalene, shown in Fig. 10). Proximity to the eutectic is important because solidification of a eutectic blend tends to give a solid with the smallest crystal size, one that least disrupts the homogeneous gel. Away from the eutectic, one of the components selectively crystallizes in the form of large plates or needles that disrupt the homogeneous gel.

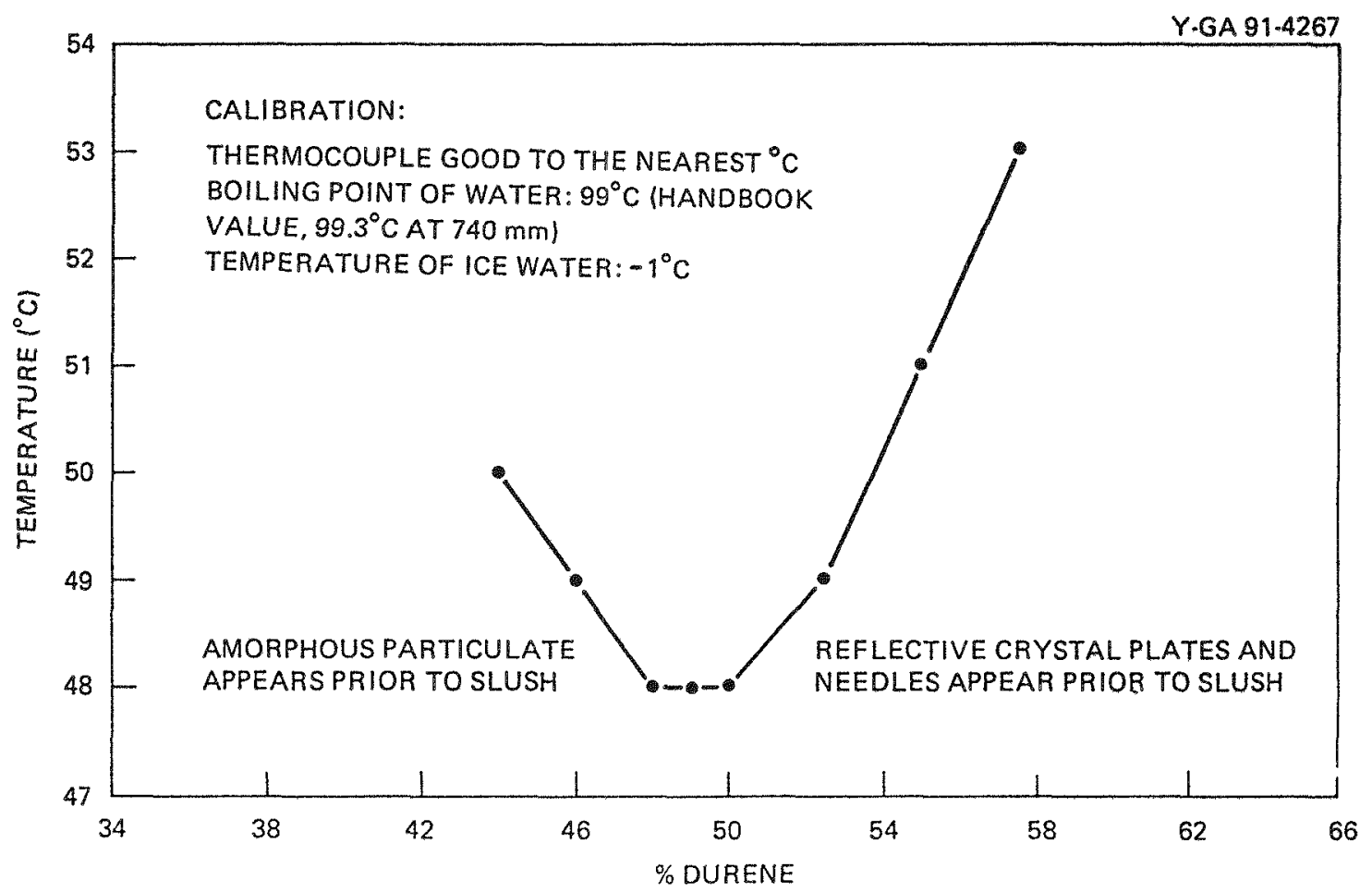

Fig. 10. Durene/naphthalene phase diagram.

In the past, durene quality was considered to have a significant impact on foam quality. Statistical verification of this experimental observation was deemed desirable; hence, durene quality was selected as a parameter. As mentioned earlier in the section Durene Purification, liquid content of the durene was found to be anathema to quality foam production. A liquid durene fraction contributed not only to radiographic inhomogeneity but also to irreproducible foam densities. Unfortunately, starting with "pure" durene did not guarantee ending with pure durene. Durene is readily oxidized and engages in free-radical reactions at elevated temperatures to produce various impurities. ${ }^{15}$ For example, significantly more liquid 
1,2,3-trimethylbenzene (pseudocumene) was found after distrilled durene was heated in air than after doubly recrystallized durene was heated in air. A statistical experiment was conducted to identify conditions that would minimize oxidation and free-radical degradation of durene. Details of this experiment are given in Appendix A.

The selection of cover gas as a parameter was also based on observation. Whenever pmp was dissolved in air, the melt discolored. The amount of discoloration was a function of both time and temperature. No discoloration occurred whenever argon was used as a cover gas. The durene quality statistical study, discussed in Appendix A, revealed that significantly more durene dimer (mol. wt 266) was produced when heating was done in air than when done with an argon cover gas. Likewise, more pseudocumene was found for distilled durene samples heated in air than under argon. The effect of this discoloration on foam quality was unknown and hence was included in this statistical study.

The final parameter chosen for statistical testing was casting configuration. Experience with casting indicated that homogeneous foams could be produced by using either the Teflon $\mathbb{B}$ cells in oil baths or the air-cooled Pyrex $(\AA)$ trays. Since the latter casting arrangement required less preparation and cleanup, and since the higher gel rate meant reducing gel time from $5 \mathrm{~h}$ to $1 \mathrm{~h}$. it became desirable to compare the efficiencies of casting using both configurations.

Quench temperature was only partially explored because the vertical orientation of the Teflon ${ }^{\circledR}$ cells and lack of proper chill capability for this orientation allowed only for the use of $0^{\circ} \mathrm{C}$ ice water. On the other hand, in the case of Pyrex ${ }^{\circledR}$ tray castings, a horizontal chill plate mounted in a pressure vessel allowed both $0^{\circ} \mathrm{C}$ and $-25^{\circ} \mathrm{C}$ quench temperatures to be explored.

In all, 48 castings were made as part of the statistical study. All castings were made in the $31-\mathrm{mg} / \mathrm{cm}^{3}$ density range with Mitsui RT18 grade of TPX $\AA$ polymer. Eight castings, along with eight duplications, were made in the Teflon $(B)$ cell/oil bath configuration and quenched only at $0^{\circ} \mathrm{C}$. The remaining 32 castings (including 16 duplicates) were made with the air-cooled Pyrex $(\mathbb{B})$ tray configuration, quenched at both $0^{\circ} \mathrm{C}$ and $-25^{\circ} \mathrm{C}$. All heating was done in covered, stirred, stainless steel hospital cans converted to teapots either in air or with argon as the cover gas. Unfortunately, the technical-grade durene on hand was of fairly high quality and did not vary markedly from lot to lot as did earlier lots of durene. Moreover, after two-stage recrystallization, the durene from both lots tested equally clean.

\section{RESULTS OF STATISTICALLY DESIGNED EXPERIMENT}

Foam quality was judged on the basis of radiographic uniformity. Acceptable foams were those whose radiographs were uniform from end to end. The results of the statistical experiment are plotted in Fig. 11 and are summarized in the following discussion.

For air-cooled Pyrex ${ }^{\circledR}$ tray castings, the following parameters and interactions were judged to be statistically significant at the $95 \%$ confidence level: quench temperature; interaction between the solvent-to-nonsolvent ratio and the quench temperature; and interaction among durene lot, cover gas, and quench temperature. Quenching 70/30 solvent blend Pyrex $\mathbb{B}$ tray castings at $-25^{\circ} \mathrm{C}$ contributed significantly to the cracking of the Pyrex $(B)$ tray castings and gave significantly poorer results than quenching these same castings at $0^{\circ} \mathrm{C}$. Solvent ratio and quench rate interactions can be further explored by comparing the second and third bar clusters of Fig. 11. Quenching of the 70/30 solvent blend Pyrex ${ }^{\circledR}$ tray castings at $-25^{\circ} \mathrm{C}$ gave significantly poorer results than either oil bath castings or Pyrex ${ }^{\circledR}$ tray castings using the 60/40

blend, primarily because of cracking of the brick. Interestingly, for the $60 / 40$ solvent blend 
alone, there was no significant difference in acceptance rate for Pyrex ${ }^{\circledR}$ tray castings quenched at $0^{\circ} \mathrm{C}$ and those quenched at $-25^{\circ} \mathrm{C}$ In other words, the $60 / 40$ solvent blend made a tougher wax that withstood thermal shock much better than did the wax made from a 70/30 solvent blend Further comparison of the results of using only the $60 / 40$ solvent blend reveals that the casting efficiency for the Teflon $\mathbb{B}$ cell/on bath was essentially the same as the efficiency for the Pyrex $\otimes^{8}$ trays quenched at either $0^{\circ} \mathrm{C}$ or $-25^{\circ} \mathrm{C}$ Table 4 further summarizes the results of this experiment

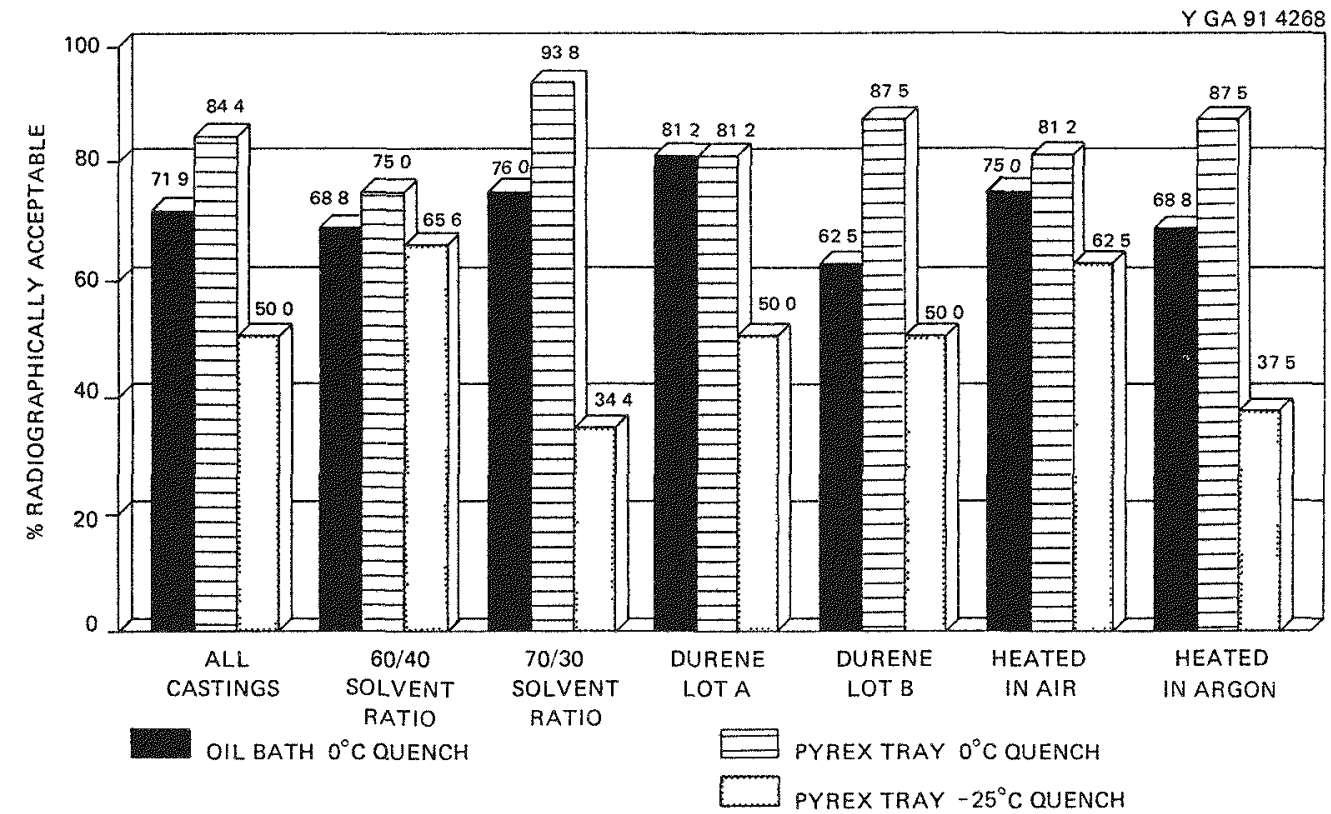

Fig. 11. Summary of statistical experiment on TPX ${ }^{\circledR}$ foam, showing comparison of casting efficiencies for the Teflon ${ }^{\circledR}$ cell/oil bath vs the Pyrex ${ }^{\circledR}$ tray.

The $938 \%$ acceptance rate for castings made by using the $70 / 30$ solvent ratio in Pyrex(B) trays and quenched at $0^{\circ} \mathrm{C}$ was sigmficantly higher than the rate for other castings made by using either the $70 / 30$ or the $60 / 40$ blends This was a remarkably high rate (as were the 65 to $75 \%$ values) compared with the dismally low (usually $<30 \%$ ) rates experienced earlier in the experimental program

As for the effect of the durene on foam quality, if we 1gnore the effects of quench temperature, lot B appeared to produce significantly better Pyrex ${ }^{\circledR}$ tray castings than oil bath castings Durene lot A produced equally acceptable castings in either casting configuration. Because of the similar purity levels of the starting materials, these results were puzzling and unexplainable

Regarding the role of the cover gas, if quench temperature is again ignored, casting done under an argon cover was not better than, or was at best marginally better than, castings done in air in either the on bath or the Pyrex ${ }^{B}$ tray Melts exposed to air discolored with time at $150^{\circ} \mathrm{C}$ trom colorless to various shades of yellow or gold Melts heated under argon did not discolor Nevertheless, according to the statistics, color change apparently had little to do with resulting foam quality 


\section{Explanation of table entries}

Yes: A significant difference in acceptance rates at $95 \%$ confidence level.

No: No significant difference in acceptance rates at $95 \%$ confidence level

Marginal: A marginal difference in acceptance rates (a significant difference at $90 \%$ confidence level but no significant difference at $95 \%$ confidence level)

\begin{tabular}{llll}
\hline Data grouping & $\begin{array}{c}\text { Oil bath } \\
\text { vs } \\
\text { tray }\left(0^{\circ} \mathrm{C}\right)\end{array}$ & $\begin{array}{c}\text { Oil bath } \\
\text { vs } \\
\text { tray }\left(-25^{\circ} \mathrm{C}\right)\end{array}$ & $\begin{array}{c}\text { Tray }\left(0^{\circ} \mathrm{C}\right) \\
\text { vs } \\
\text { tray }\left(-25^{\circ} \mathrm{C}\right)\end{array}$ \\
\hline All data & Marginal & Yes & Yes \\
$60 / 40$ & No & No & No \\
$70 / 30$ & Yes & Yes & Yes \\
Lot A & No & Yes & Yes \\
Lot B & Yes & No & Yes \\
Air & No & No & Marginal \\
Argon & Marginal & Yes & Yes \\
\hline
\end{tabular}

In a comparison of the acceptance rates based on quench rates $\left(0^{\circ} \mathrm{C}\right.$ vs $\left.-25^{\circ} \mathrm{C}\right)$ for tray castings heated under argon vs tray castings heated air, it is interesting to speculate why argon castings quenched at $-25^{\circ} \mathrm{C}$ cracked more easily than did those heated in air and also quenched at $-25^{\circ} \mathrm{C}$. For this reason, more data were collected. Various qualities of pmp foam were extracted by Freon ${ }^{\circledR} 113$ and then analyzed by GC-MS. The experiment and results are discussed in detail in Appendix A. In general, the data indicated that significantly more impurities were produced when singly recrystallized/distilled (as compared with doubly recrystallized) durene was used and when heating was done in air. Waxes subjected to heating in air, therefore, produced more plasticizing impurities that may have acted to moderate brittleness. Furthermore, because of increased peroxidation and free-radical activity, the polymer in these same samples may have experienced increased cross linking (in addition to chain scission), which would have also contributed to the toughness of the wax. For waxes heated under an argon blanket and in the absence of strong ultraviolet excitation, very little initiating peroxidation and subsequent free-radical cross linking are anticipated. Likewise, lower concentrations of plasticizing organics, with the resultant production of a more brittle wax, are anticipated. 


\section{NONSOLVENTS THAT REDUCE DENSITY DIFFERENCES BETWEEN SOLVENT AND GEL}

At various times during the experimental project, gelation was observed in beakers illuminated from the rear by bright white light. Gelation almost always proceeded nonuniformly from the bottom of the beakers. Streamers of polymer were often seen to rise from nucleation sites on the bottom of the beakers, just above the gel. Formation of these streamers was attributed to density differences between the solvent-swollen gel and the solvent. To reduce this difference and thereby produce a more homogeneous gel, a search was begun for a nonsolvent that had a lower density than naphthalene $\left(d=1.025 \mathrm{~g} / \mathrm{cm}^{3}\right.$ at $\left.20^{\circ} \mathrm{C}\right)$ and one that would function like naphthalene to initiate phase inversion. In order first to determine the density of RT18 near the gel inversion temperature $\left(110^{\circ} \mathrm{C}\right)$, a few pellets of RT18 were immersed in a binary solution consisting of octadecane $\left(d=0.777 \mathrm{~g} / \mathrm{cm}^{3}\right.$ at $\left.20^{\circ} \mathrm{C}\right)$ and durene $\left(d=0.888 \mathrm{~g} / \mathrm{cm}^{3}\right.$ at $20^{\circ} \mathrm{C}$ ). The solvent-swollen pellets hovered in a solution composed of $87 \mathrm{wt} \%$ durene and 13 wt $\%$ octadecane at a density of $0.787 \mathrm{~g} / \mathrm{cm}^{3}$ (at $111^{\circ} \mathrm{C}$ ). Unfortunately, both durene and hexadecane were good solvents for TPX® and failed to force phase inversion of the polymer before the solvent solidified.

An investigation of the density of durene/naphthalene solvent/nonsolvent blends was pursued at this point. Figure 12 shows the results of this investigation. This figure illustrates that, as the density of durene/naphthalene blends approaches that of the RT18 polymer $(0.787$ $\left.\mathrm{g} / \mathrm{cm}^{3}\right)$ at $110^{\circ} \mathrm{C}$, the durene/naphthalene ratios move farther from the desirable $49 / 51 \mathrm{wt} \%$ eutectic ratio. Hence, making adjustments to lower the density of the durene/naphthalene solvent blend to improve the uniformity of the gel moves the solvent blend into a region where disruption of the gel by crystallization increasingly becomes a problem. Other nonsolvent candidates were therefore investigated.

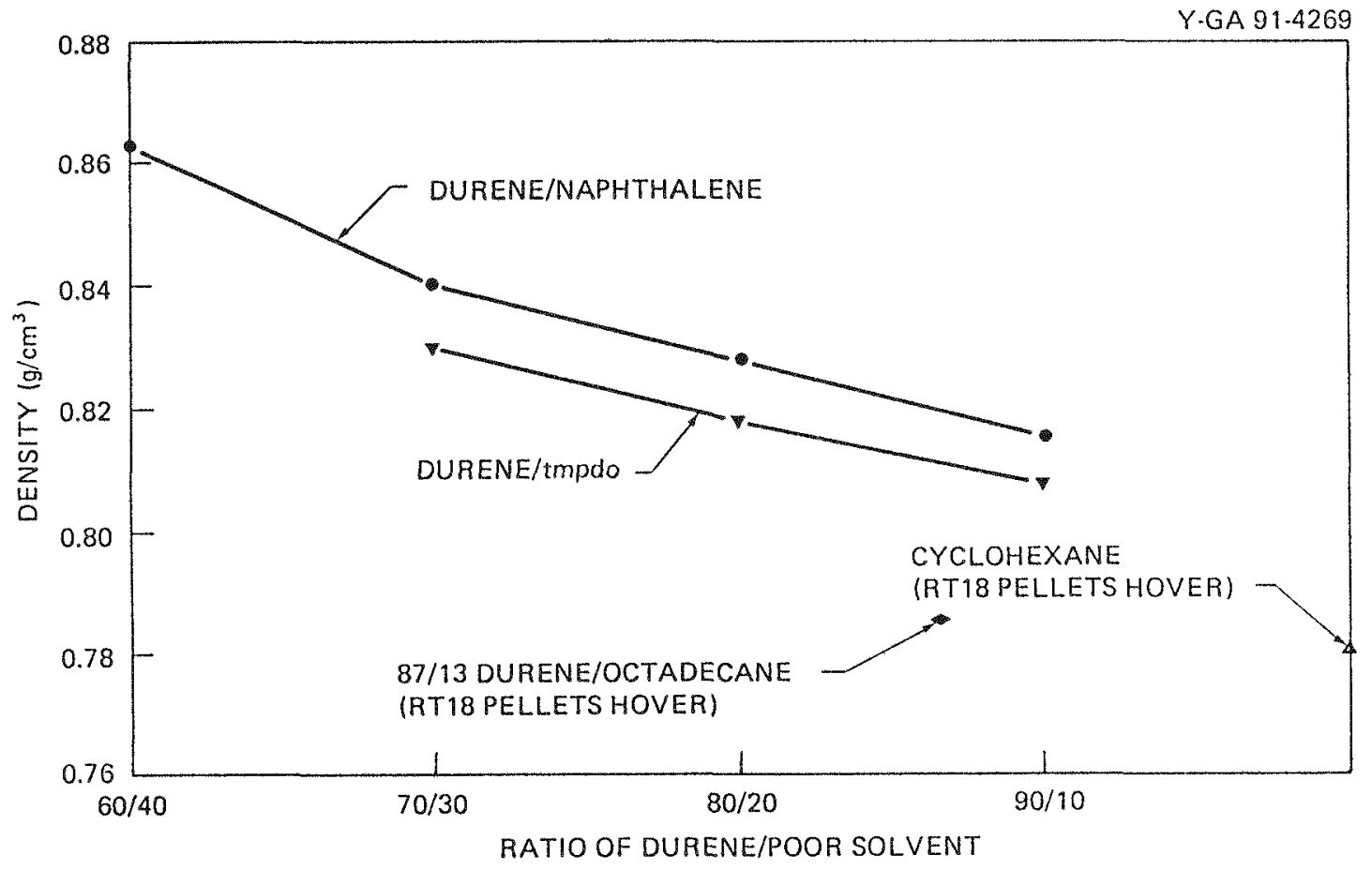

Fig. 12. Density of durene/poor solvent mixtures at $\sim 110^{\circ} \mathrm{C}$. 
The first candidiate to be investigated was 1-hexadecanol, a solid at room temperature (melting point of $50^{\circ} \mathrm{C}$ ) that exhibited very little attack on pmp at elevated temperatures. With a density of $0.818 \mathrm{~g} / \mathrm{cm}^{3}$ at $50^{\circ} \mathrm{C}$, hexadecanol appeared to be a good candidate for reducing density-induced defects in the gel. A phase diagram for the durene/hexadecanol solvent system was determined and is shown in Fig. 13. The low durene content and high hexadecanol content at the eutectic ( $23 \mathrm{wt} \%$ durene $/ 77 \mathrm{wt} \%$ hexadecanol) presented a problem for dissolving the pmp. Pmp was first dissolved in durene at $175^{\circ} \mathrm{C}$, and molten hexadecanol at $175^{\circ} \mathrm{C}$ was slowly added to this durene/pmp solution. After being thoroughly stirred, the solution was poured into a $180^{\circ} \mathrm{C}$ Pyrex ${ }^{\circledR}$ tray and observed during gelation. Gelation began at $173^{\circ} \mathrm{C}$ and occurred by the interconnecting of growing spherulites in a manner similar to that described in the literature. ${ }^{16}$ At $90^{\circ} \mathrm{C}$, gelation appeared to be complete. At this point, the gel was quite stiff and appeared to be nearly transparent. The gel was moved to a $0^{\circ} \mathrm{C}$ chill plate in a pressure vessel and frozen under pressure as described earlier. The resulting wax was more friable than similar durene/naphthalene waxes, yet was strong enough to handle without damage.

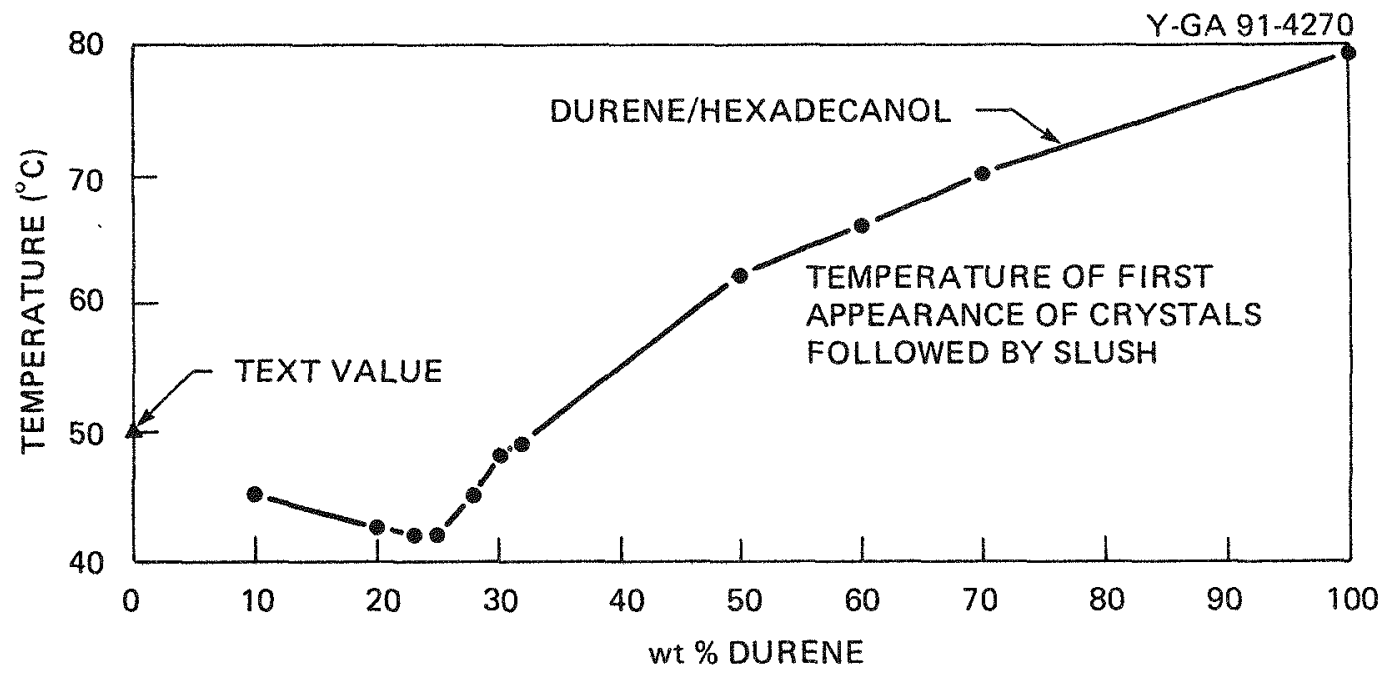

Fig. 13. Phase diagram for durene/hexadecanol.

The vapor pressure of hexadecanol at temperatures below the melting point is very low; hence, some technique other than sublimation was required to extract it from the foam. The durene/hexadecanol/pmp samples were therefore sent to Sandia National Laboratory, Albuquerque, for solvent extraction using supercritical $\mathrm{CO}_{2}$. The extracted foam proved to be quite uniform, yet slightly more grainy than corresponding pmp foams made with durene and naphthalene.

The second candidate that was nonsolvent-tested was 2,2,4-trimethyl-1,3-pentanediol. The commercial grade of tmpdo that was used contained a fair amount of polyols and hence was purified before use by recrystallization from Freon ${ }^{\circledR} 113$. With a melting point of $51^{\circ} \mathrm{C}$ and a density of $0.937 \mathrm{~g} / \mathrm{cm}^{3}$ at $15^{\circ} \mathrm{C}$, tmpdo appeared to be another good candidate as a nonsolvent. With a density less than that of naphthalene but higher than that of hexadecanol, tmpdo was not expected to alleviate density-induced gel defects as well as hexadecanol. However, with the diol functionality, tmpdo proved to be much more of a nonsolvent for pmp than naphthalene, and it was hoped that very little would be required to induce phase inversion. A phase diagram was first determined for the durene/tmpdo system to determine the best starting ratio of durene and 
tmpdo and to determine if a eutectic existed. This diagram is shown in Fig. 14. No eutectic was found for the durene/tmpdo system. The graph plots temperatures (and isotherms) at which crystals were first detected for each solvent/nonsolvent ratio. Pure tmpdo exhibited supercooling before crystallization, as did a blend consisting of $95 \%$ tmpdo and 5 wt $\%$ durene. This blend cooled to a clear gel at $7^{\circ} \mathrm{C}$ before suddenly forming a fine "snow," at which point it exothermed to $41^{\circ} \mathrm{C}$.

After some preliminary experimentation, a solvent blend consisting of $70 \mathrm{wt} \%$ durene and $30 \mathrm{wt} \%$ tmpdo was determined to produce firm, opalescent, nearly transparent, defect-free TPX ${ }^{\circledR}$ gels. The $30 \mathrm{wt} \%$ tmpdo initiated phase inversion at 113C. Large castings with densities of 27 and $37 \mathrm{mg} / \mathrm{cm}^{3}$ were made in Pyrex ${ }^{\circledR}$ trays. Samples were cut from these castings and shipped to Sandia National Laboratory, Albuquerque, for supercritical $\mathrm{CO}_{2}$ extraction. As with hexadecanol, the vapor pressure of the tmpdo was too low to allow removal by sublimation. Both castings produced radiographically uniform foams. Figures 15 and 16 show SEM photomicrographs of the 27 - and $37-\mathrm{mg} / \mathrm{cm}^{3}$ foams, respectively, produced with the $70 / 30$ durene/tmpdo solvent blend. Both foams were open-celled foams with uniform morphology. Straying from the $70 / 30$ ratio produced foams that were disrupted by crystallization of the solvent. Figure 17, for example, shows an SEM photomicrograph of a pmp foam produced with an 80/20 durene/tmpdo solvent blend. A definite "ladder" structure is visible that had separated from the melt. This ladder structure was even more pronounced when a $90 / 10$ durene/tmpdo blend was employed.

Discussion and photomicrographs of pmp foams made with other interesting nonsolvents can be found in Ref. 4.

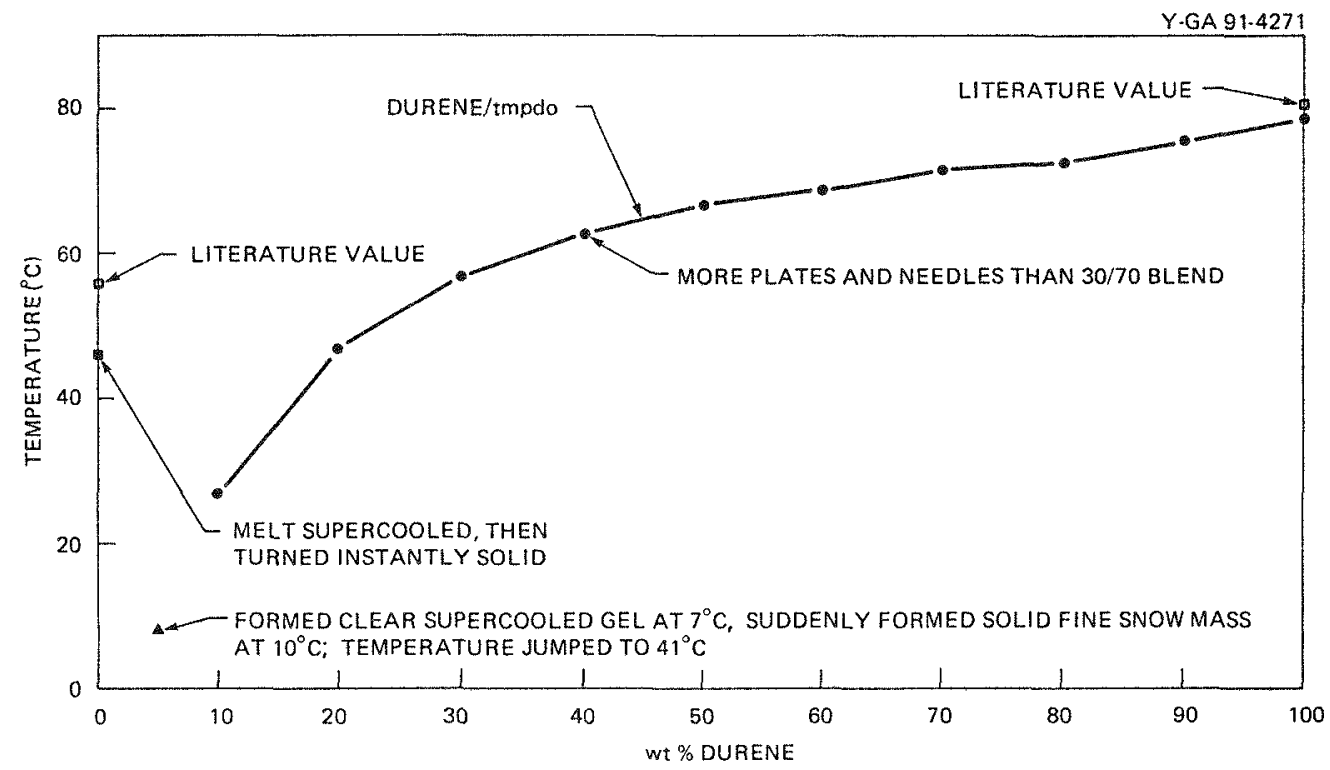

Fig. 14. Phase diagram for durene/tmpdo system. 


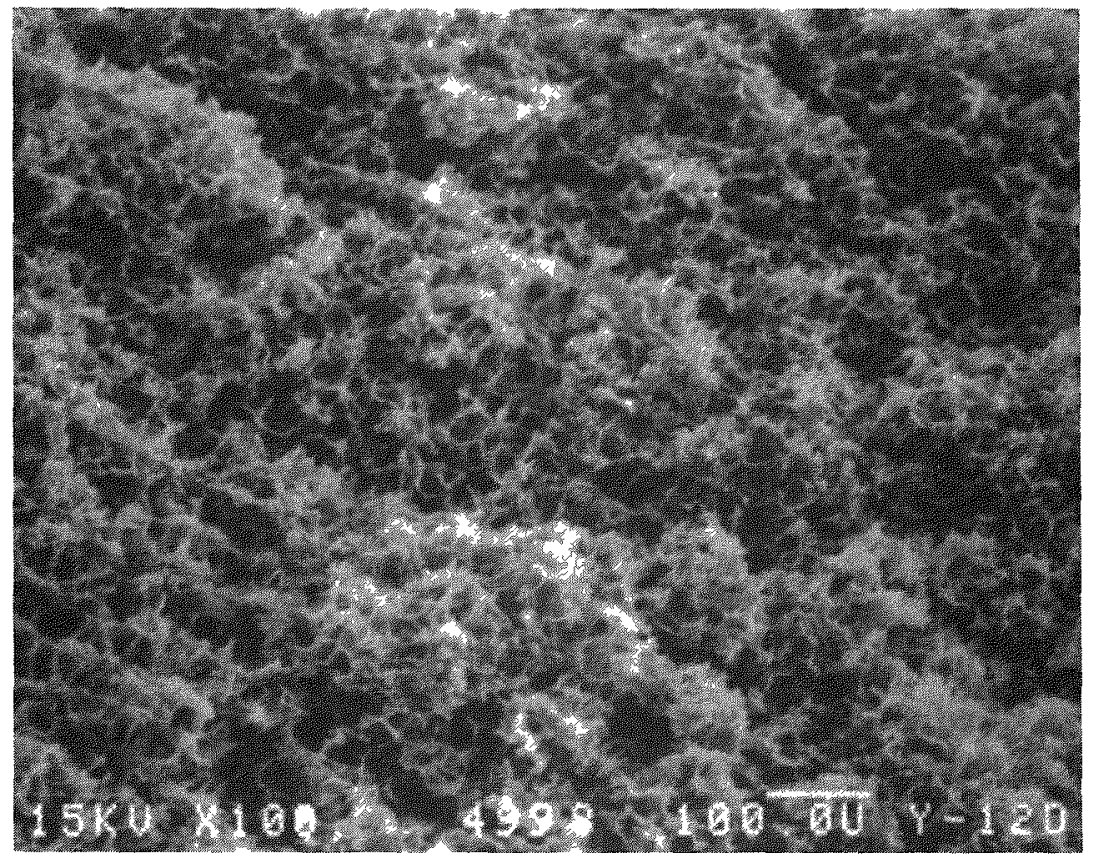

(a)

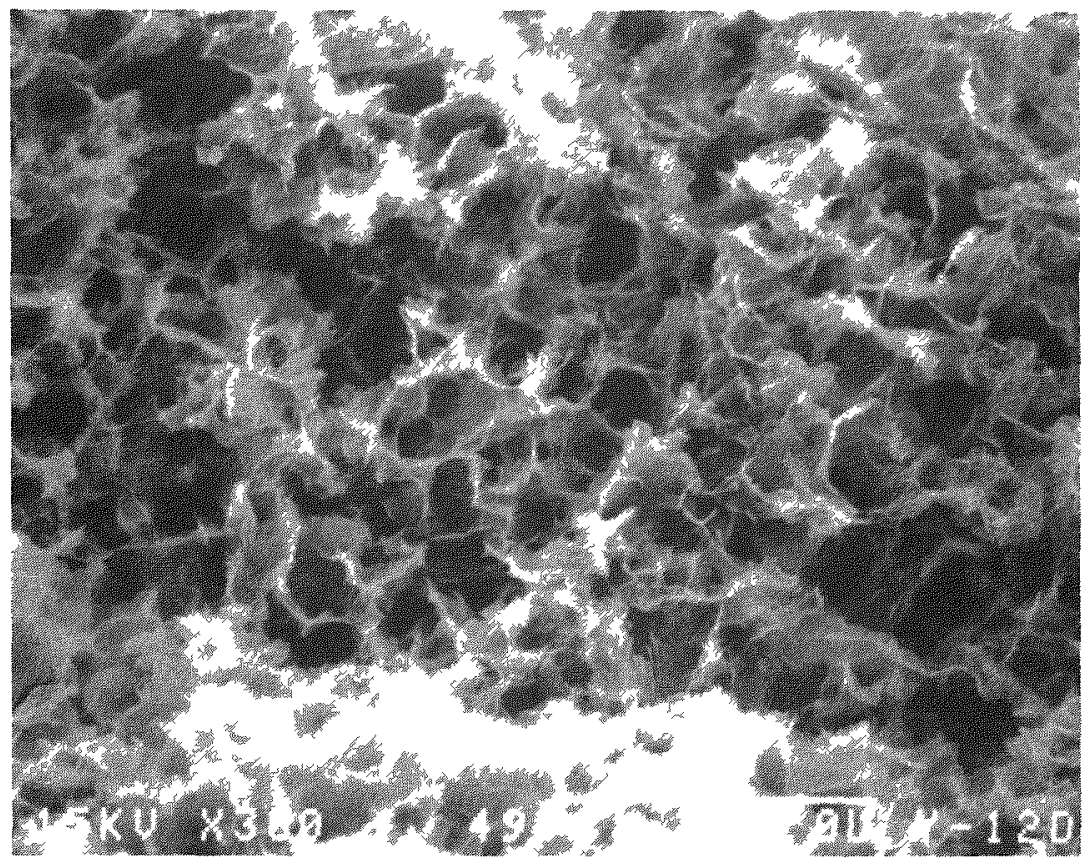

(b)

Fig. 15. SEM photomicrographs of a $27-\mathrm{mg} / \mathrm{cm}^{3}$ TPXß foam sample made with a 70/30 durene/tmpdo solvent blend, with solvent removed by supercritical $\mathrm{CO}$ extraction: (a) $100 \times$; (b) $300 \times$. 


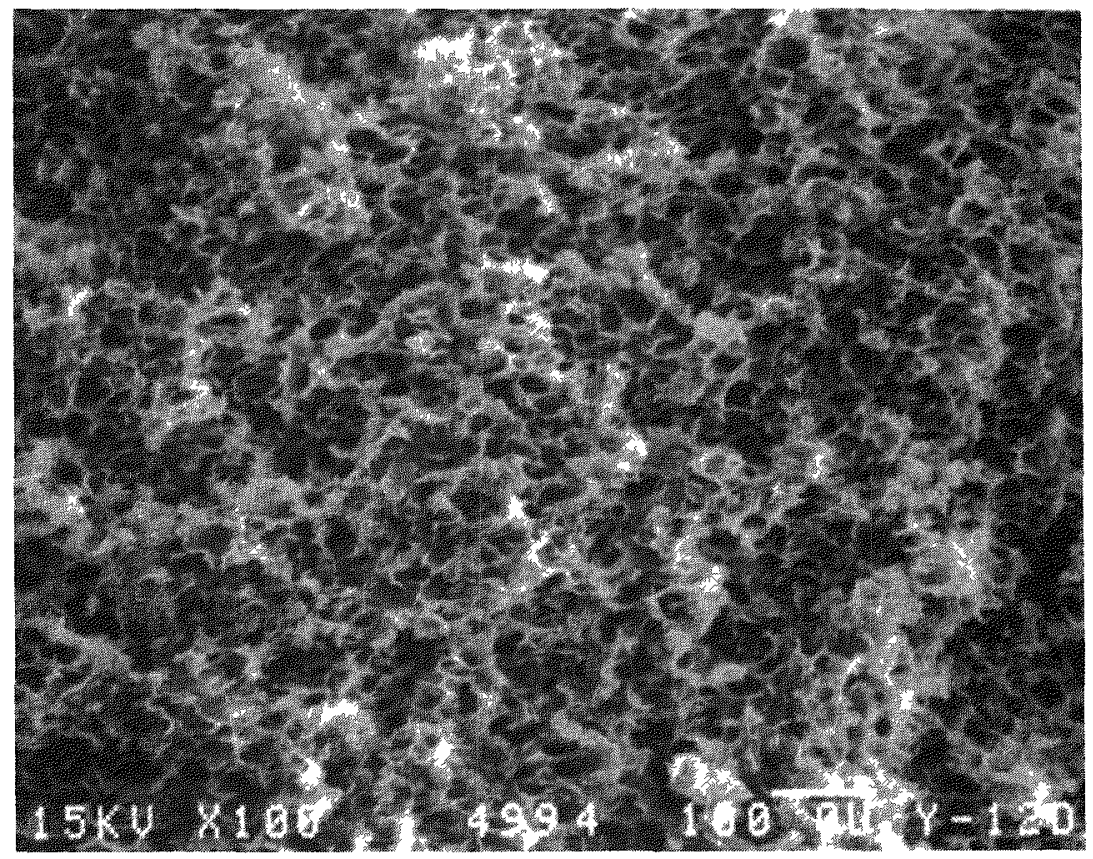

(a)

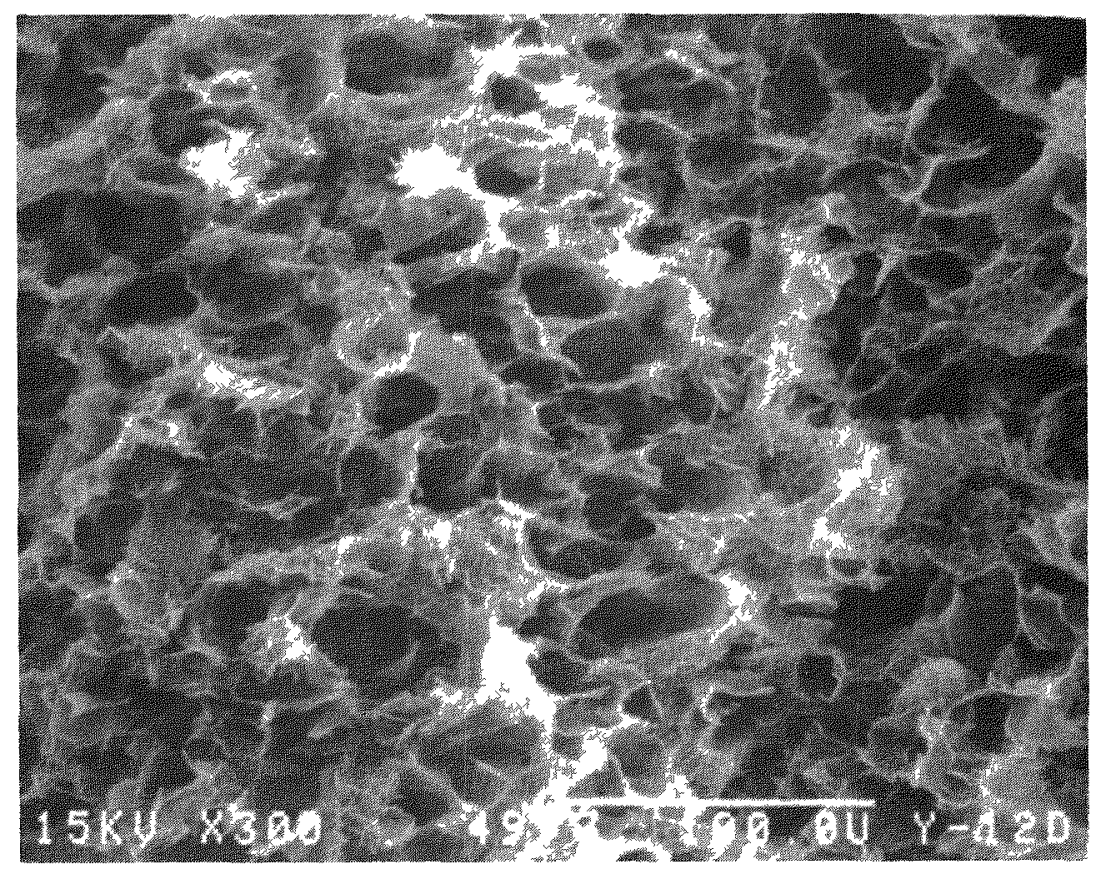

(b)

Fig. 16. SEM photomicrographs of a $37 \mathrm{mg} / \mathrm{cm}^{3}$ TPX $($ foam sample made with a 70/30 durene/tmpdo solvent blend, with solvent removed by supercritical $\mathrm{CO} 2$ extraction: (a) 100x; (b) $300 \times$ 


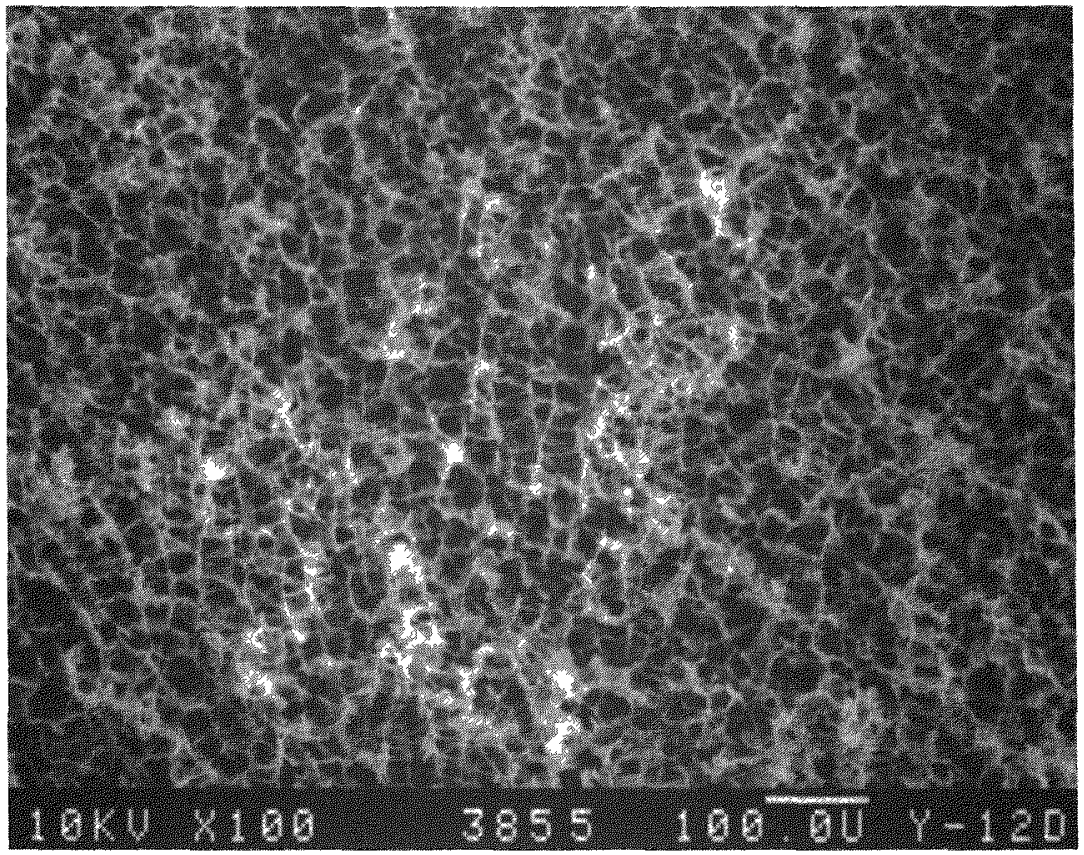

(a)

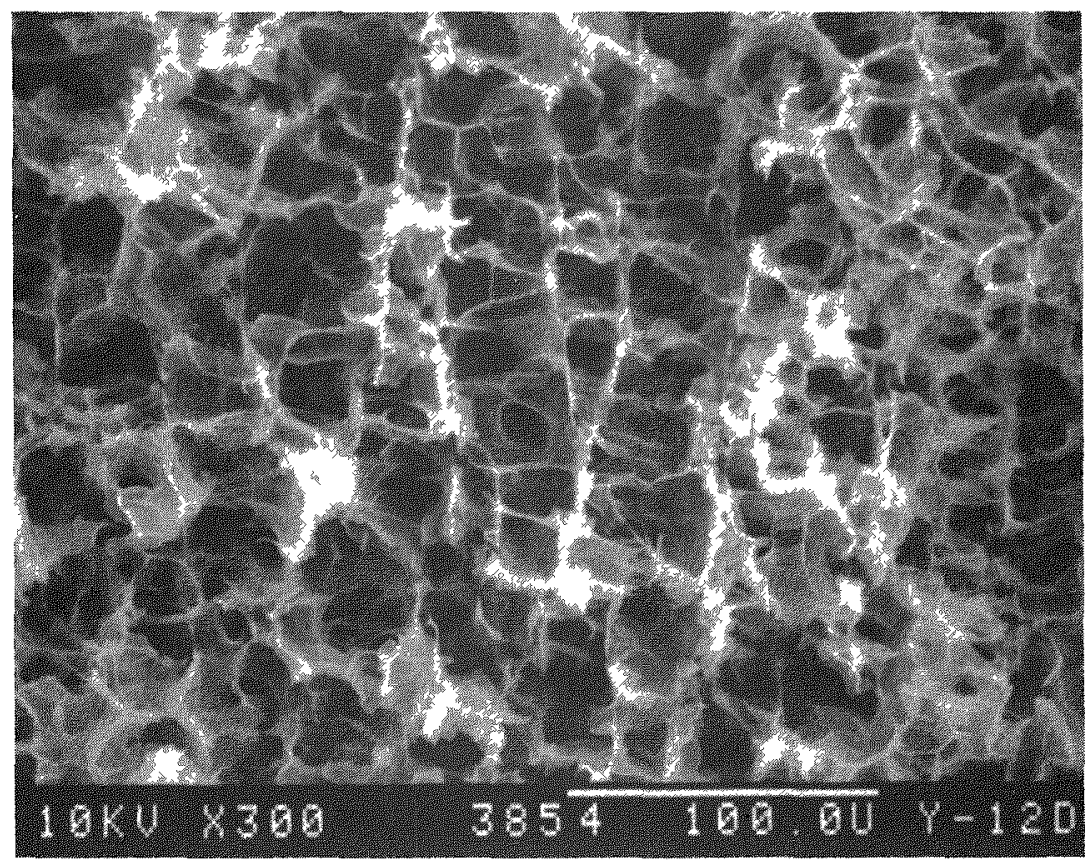

(b)

Fig. 17. SEM photomicrographs of a $36-\mathrm{mg} / \mathrm{cm}^{3}$ TPX (B) foam sample made with an 80/20 durene/tmpdo solvent blend: (a) 100\%, (b) $300 \times$ 


\section{DENSITY OF FOAM PRODUCT AS A FUNCTION OF ADDED POLYMER (VERY-LOW-DENSITY TPX® FOAMS)}

The final density of TPX® foam tracked linearly with the quantity of TPX® polymer initially added to the melt. This was true for casting in both the Teflon ${ }^{\circledR}$ cells and the Pyrex ${ }^{\circledR}$ trays, provided the purity of the durene used was high. Figure 18 shows this relationship for the Teflon ${ }^{\circledR}$ castings, and Fig. 19 illustrates this for the Pyrex ${ }^{\circledR}$ tray castings. Lower-density foams $\left(5 \mathrm{mg} / \mathrm{cm}^{3}\right)$ were obtained with the Pyrex $(\circledR)$ trays. Data for both graphs apply to TPX® foam produced with purified durene. Experimental scatter increased drastically when impure durene was used.

Various solvent ratios were used to produce the foams whose density data are shown in Figs. 18 and 19. The density data shown in Fig. 18 correspond to foams produced with both the $60 / 40$ and the 70/30 durene/naphthalene ratio. As explained earlier, to produce uniform, high-density pmp foams in the $30-$ to $50-\mathrm{mg} / \mathrm{cm}^{3}$ range required the use of a $70 / 30$ durene/naphthalene ratio. This ratio provided higher solubilizing character for the higher concentration of polymer in the melt. Fortunately, enough polymer was present to give a gel sufficiently strong to avoid disruption during crystallization of the solvent. Lower-density (20to $30-\mathrm{mg} / \mathrm{cm}^{3}$ ) foams required a solvent blend closer to the $49 / 51$ durene/naphthalene eutectic to avoid disruption during crystallization of the solvent. The $60 / 40$ blend was used in this range.

Foams cast in Pyrex ${ }^{\circledR}$ trays (see Fig. 19) and having densities in the $29-$ to $45-\mathrm{mg} / \mathrm{cm}^{3}$ range were produced by using the 70/30 durene/naphthalene solvent blend and Mitsui RT18. Below $29 \mathrm{mg} / \mathrm{cm}^{3}$, gross crystallization of durene from the $70 / 30$ blend disrupted the gel significantly. This is shown in Fig. 20, which is a photomicrograph of a $19.3-\mathrm{mg} / \mathrm{cm}^{3} \mathrm{pmp}$ foam produced with the 70/30 solvent blend. Crystalline disruption is greatly reduced and foam homogeneity is improved with the use of a $60 / 40$ solvent blend. This is shown in Fig. 21, which is a photomicrograph of a $21-\mathrm{mg} / \mathrm{cm}^{3}$ pmp foam produced with the $60 / 40$ blend. Further improvement is obtained by using the 49/51 eutectic as shown in Fig. 22. This figure shows an SEM photomicrograph of a $10.3-\mathrm{mg} / \mathrm{cm}^{3}$ foam made with the $49 / 51$ durene/naphthalene eutectic. A small amount of directionality appears to be detectable, and this may have resulted from directional cooling.

Soft yet handleable pmp foams were produced at the $6.7-\mathrm{mg} / \mathrm{cm}^{3}$ density level (Fig. 23) with the 49/51 durene/naphthalene eutectic and Mitsui high-molecular-weight DX845 TPX®). Homogeneous, lower-density TPX ${ }^{\circledR}$ foams were produced, but these foams were difficult to handle without damage. An SEM photomicrograph of a $5.1-\mathrm{mg} / \mathrm{cm}^{3}$ foam is shown in Fig. 24 . Despite an increasing concentration of larger pores as densities decrease, the overall morphology remains quite uniform. The $5.1-\mathrm{mg} / \mathrm{cm}^{3}$ foam was too soft to handle without damage and was easily blown about by room air currents. Attempts to produce pmp foams at the $2.5-\mathrm{mg} / \mathrm{cm}^{3}$ density level resulted in a poorly formed, weak foam with extensive collapsed regions. These foams crumbled when handled.

In Fig. 19, are two data points for pmp (RT18) foams produced by using a 70/30 solvent blend of durene and tmpdo. The solvent was extracted from these foams with supercritical $\mathrm{CO}_{2}$, with which some shrinkage (hence densification) is normally experienced. According to Fig. 19, this shrinkage was similar to the shrinkage experienced by durene/naphthalene foams that were processed through vacuum sublimation. The density for a $\mathrm{CO}_{2}$-extracted foam that was produced with a eutectic durene/naphthalene blend is also included in Fig. 19. Again, excessive shrinkage and densification were not encountered. 


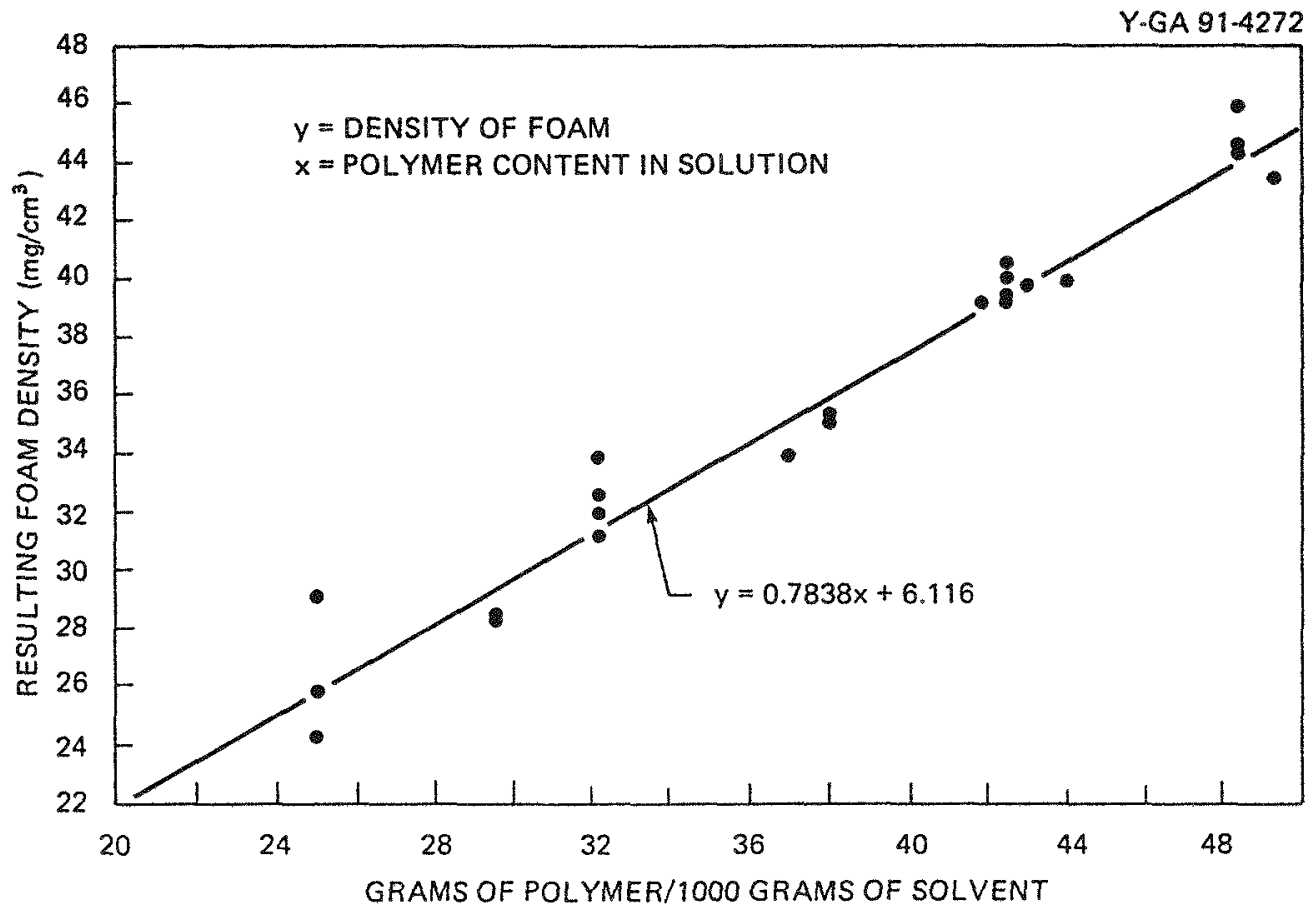

Fig. 18. Density of TPX (B) foam as a function of polymer content in solution for Teflon ${ }^{\circledR}$ cell castings.

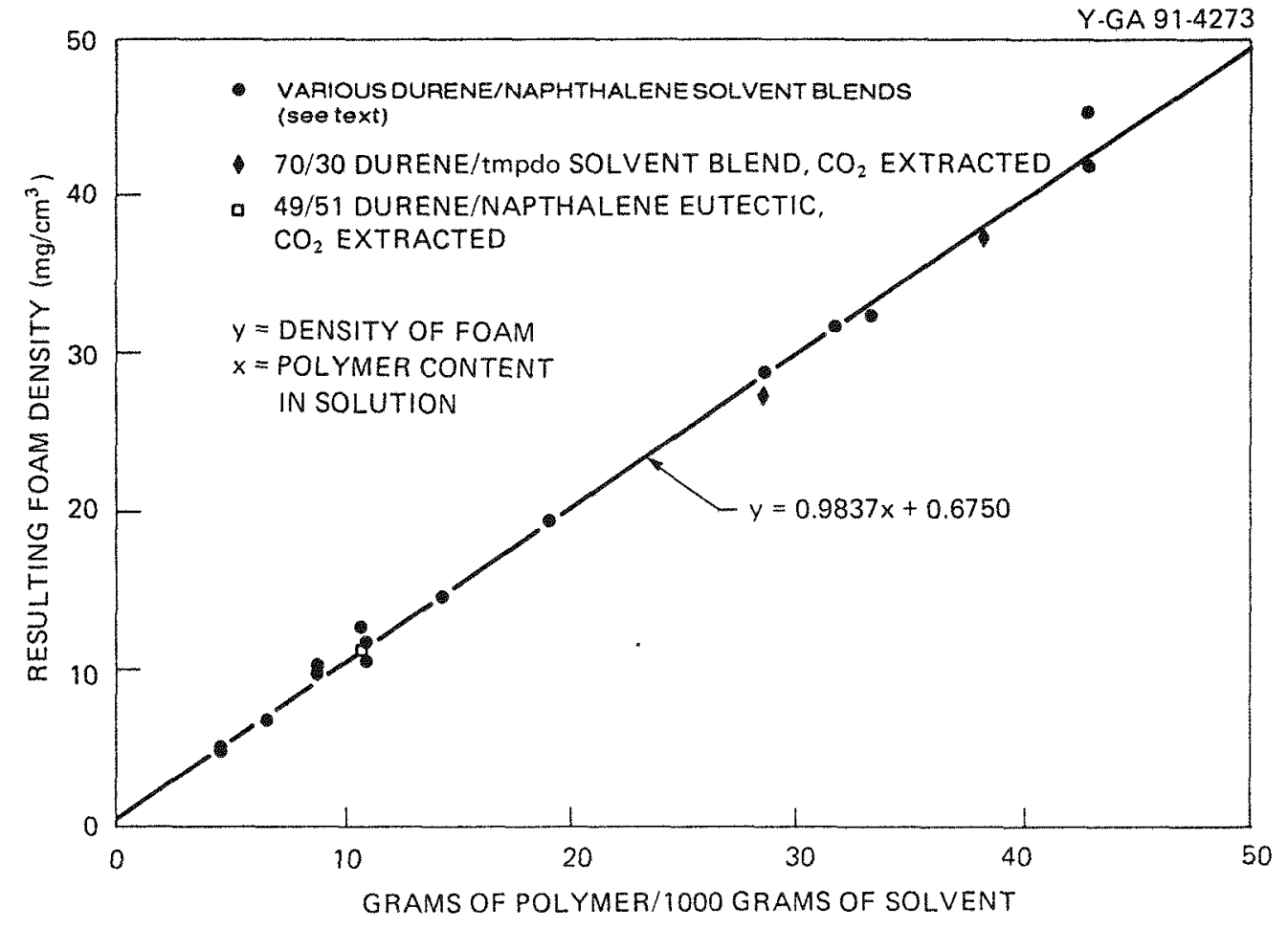

Fig. 19. Density of TPX® foam as a function of polymer content in solution for Pyrex ${ }^{\circledR}$ tray castings. 


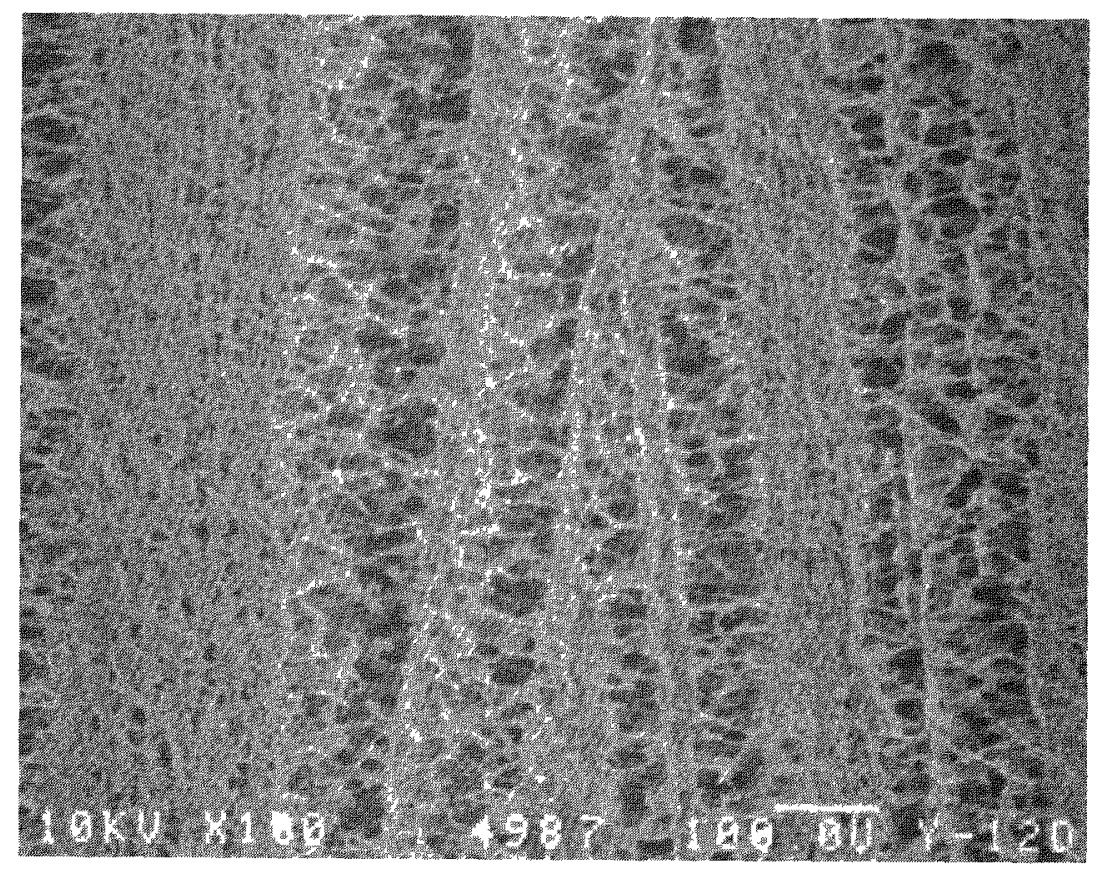

(a)

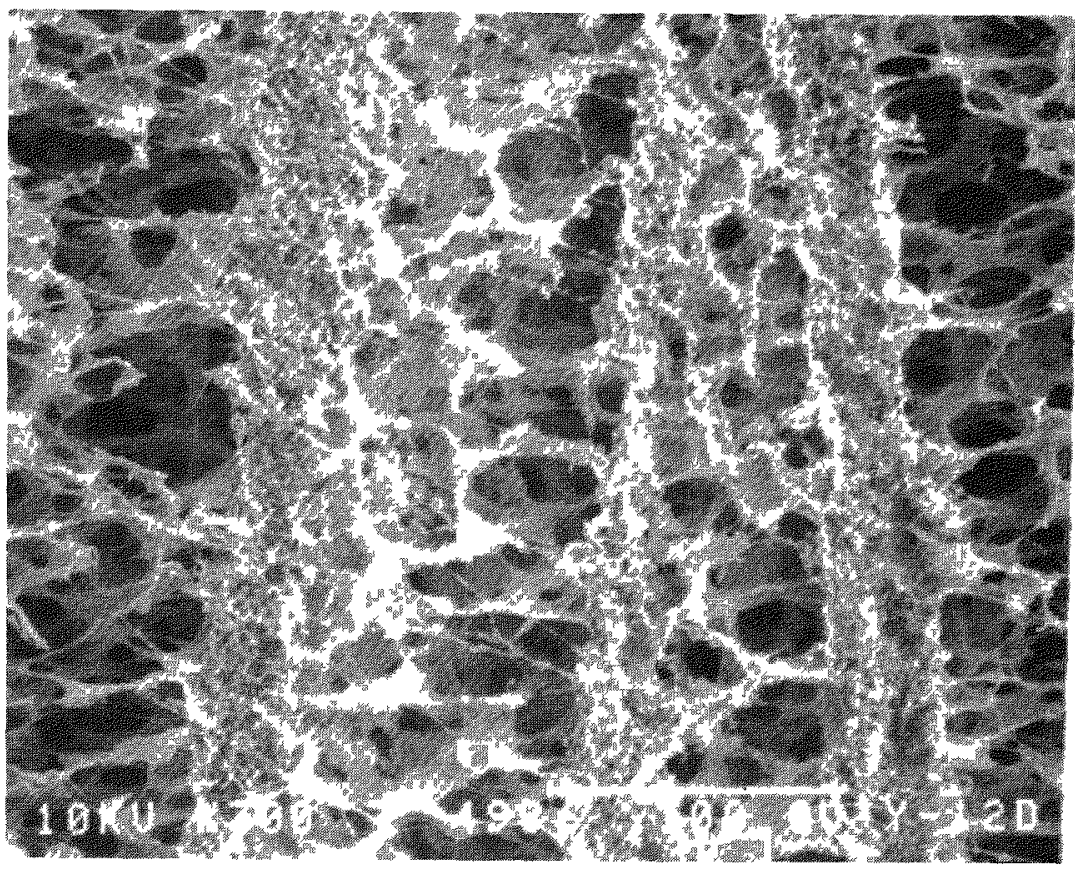

(b)

Fig. 20. SEM photomicrographs of a $19.3-\mathrm{mg} / \mathrm{cm}^{3}$ TPX(B) foam sample made with 70/30 durene/naphthalene solvent blend, with the solvent removed by sublimation: (a) $100 \times$; (b) $300 \times$. 


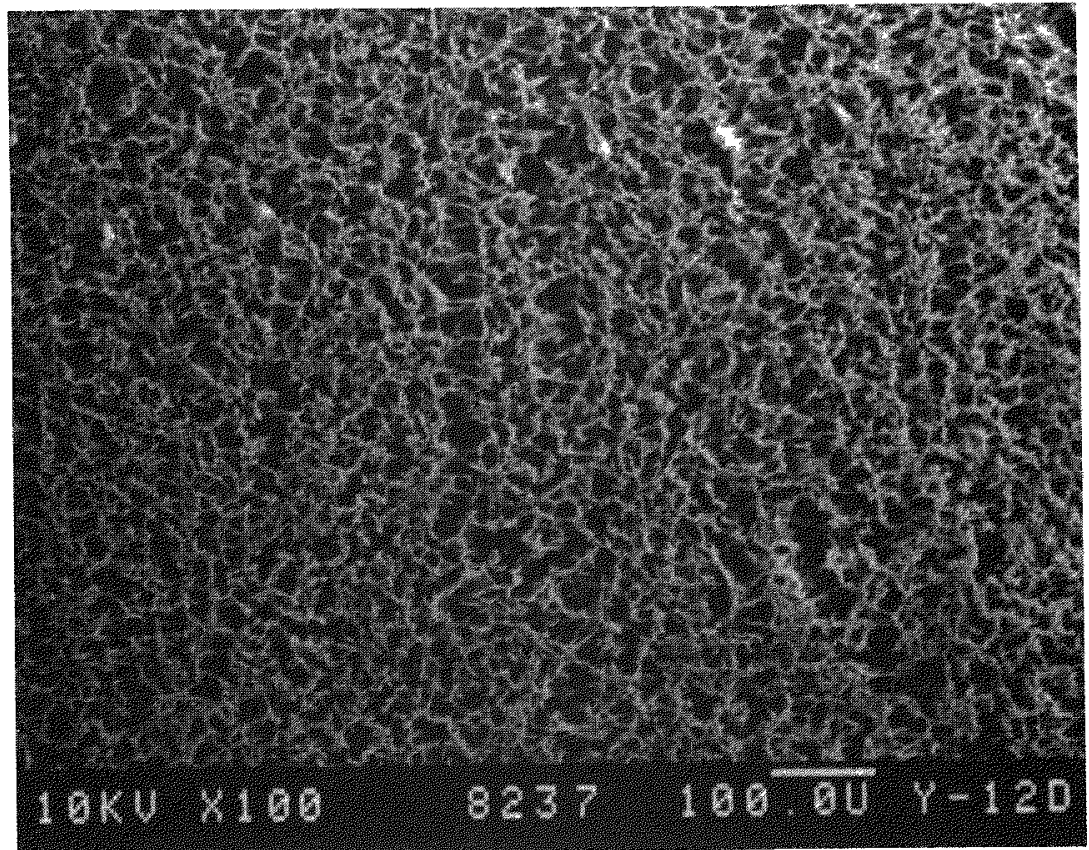

(a)

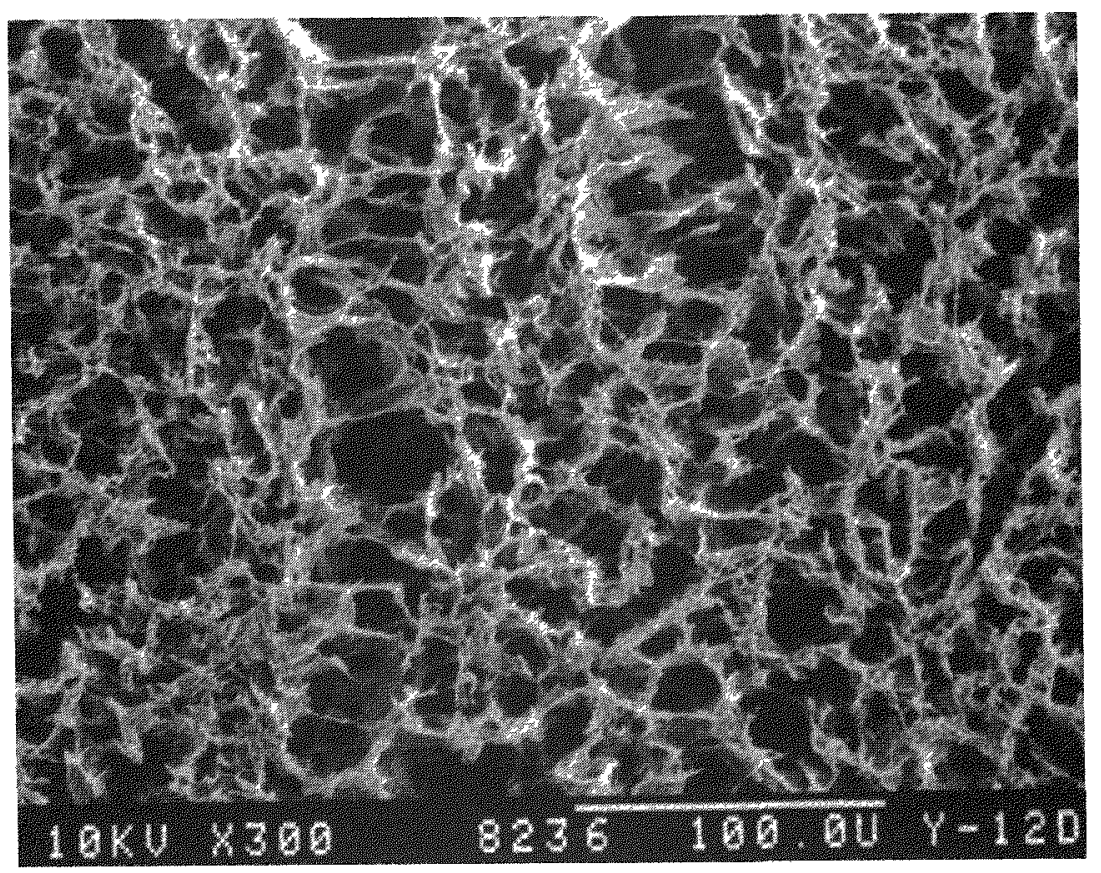

(b)

Fig. 21. SEM photomicrographs of a $21-\mathrm{mg} / \mathrm{cm}^{3}$ TPX $($ foam sample made with a 60/40 durene/naphthalene solvent blend, with the solvent removed by sublimation: (a) $100 x$; (b) $300 x$ 


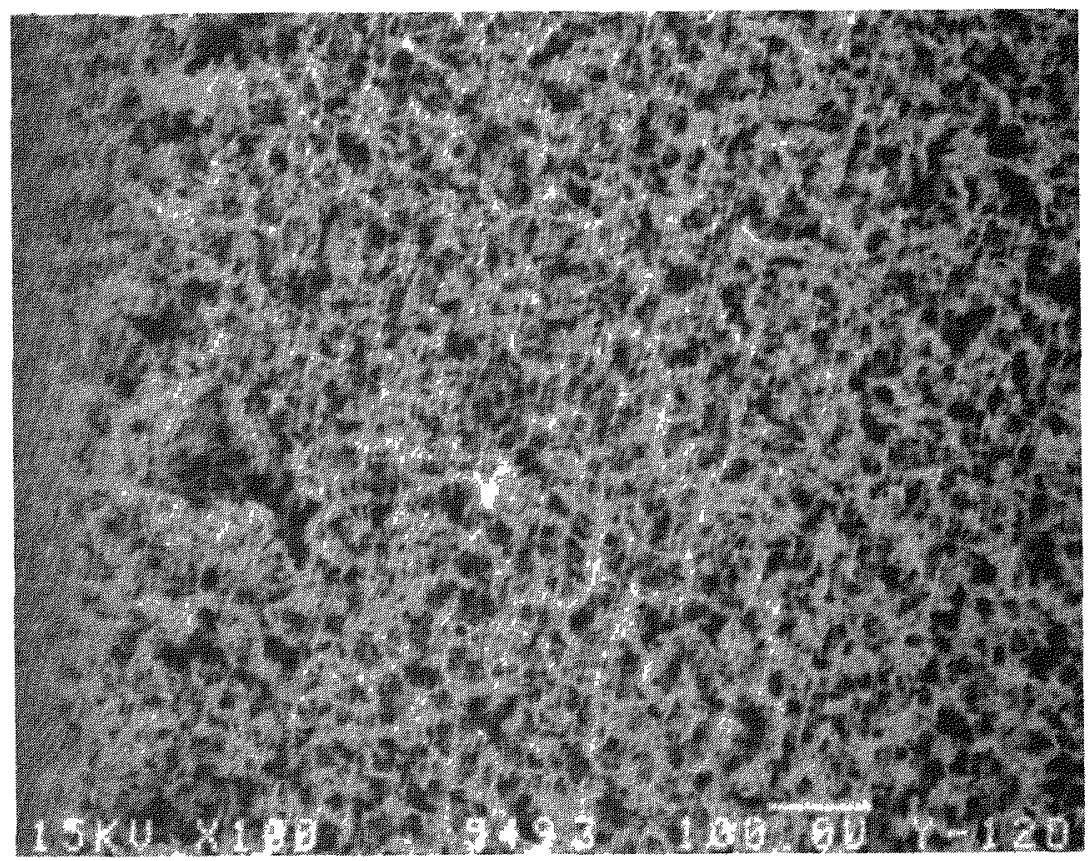

(a)

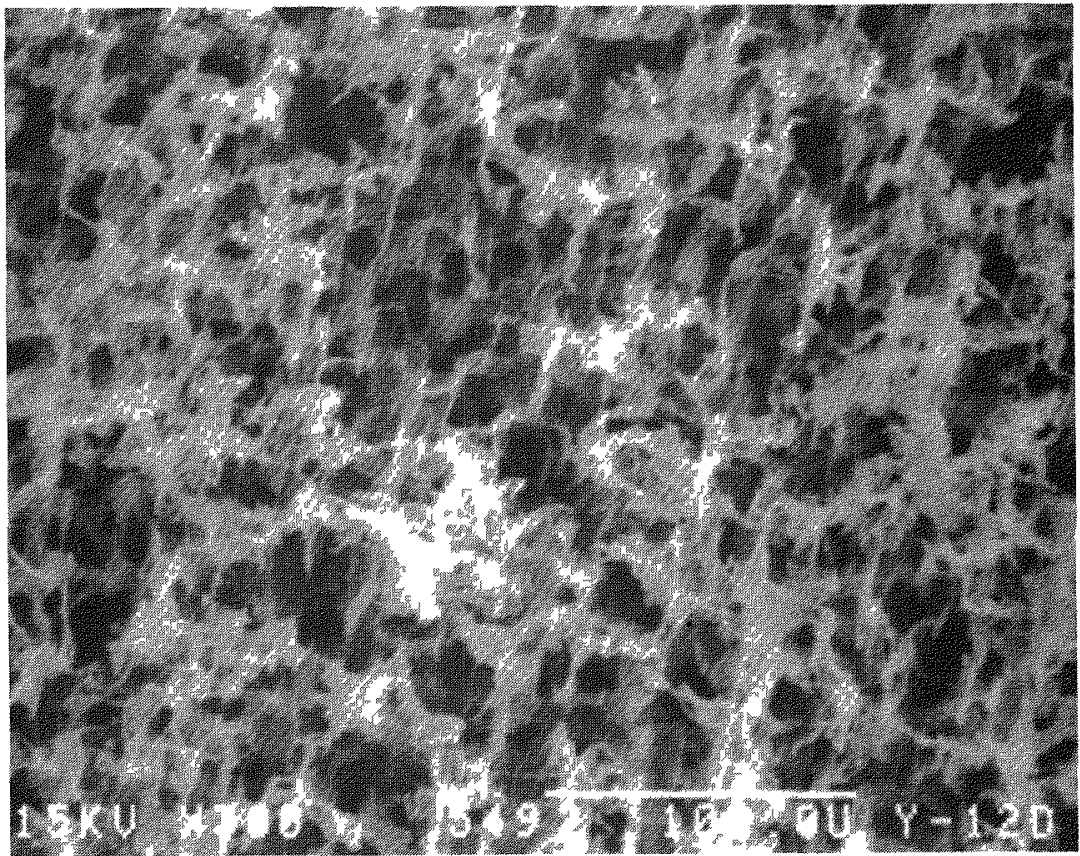

(b)

Fig. 22. SEM photomicrographs of a $10.3-\mathrm{mg} / \mathrm{cm}^{3}$ TPX $($ foam sample made with a 49/51 durene/naphthalene solvent eutectic, with the solvent removed by sublimation: (a) $100 \times$; (b) $300 \times$ 


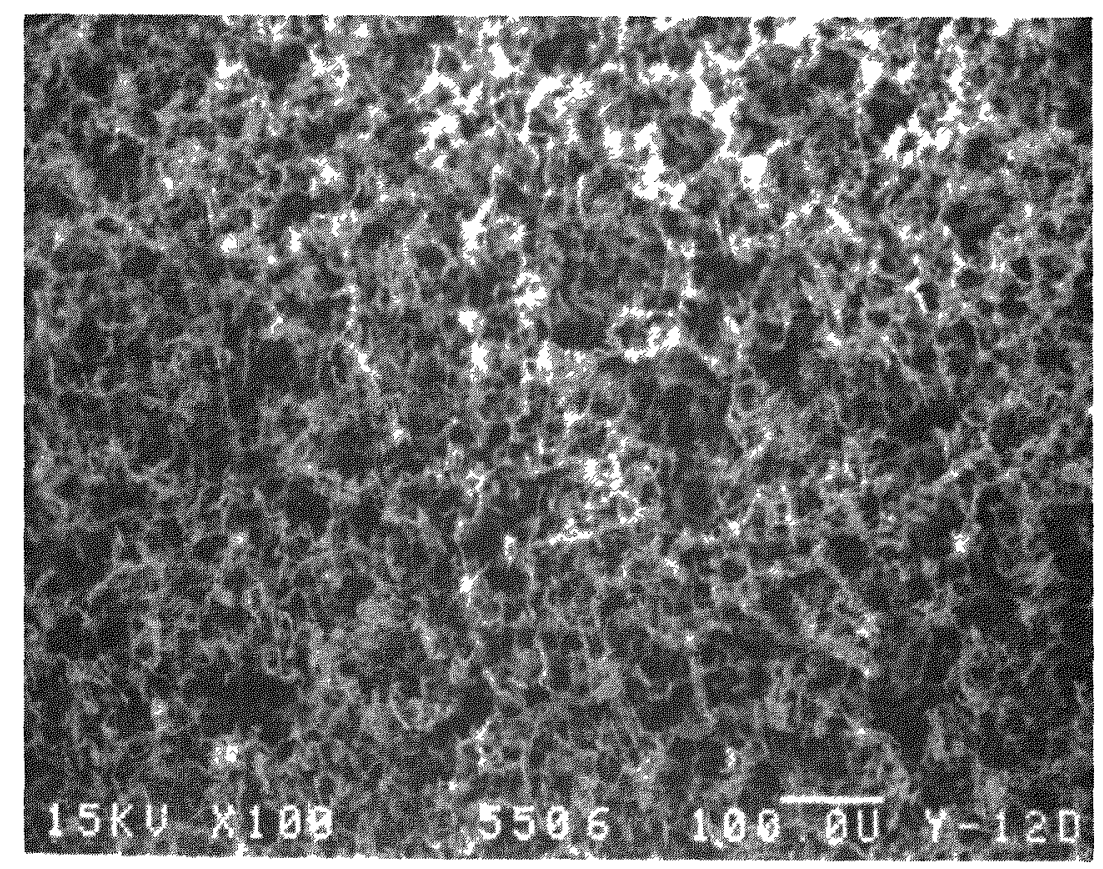

(a)

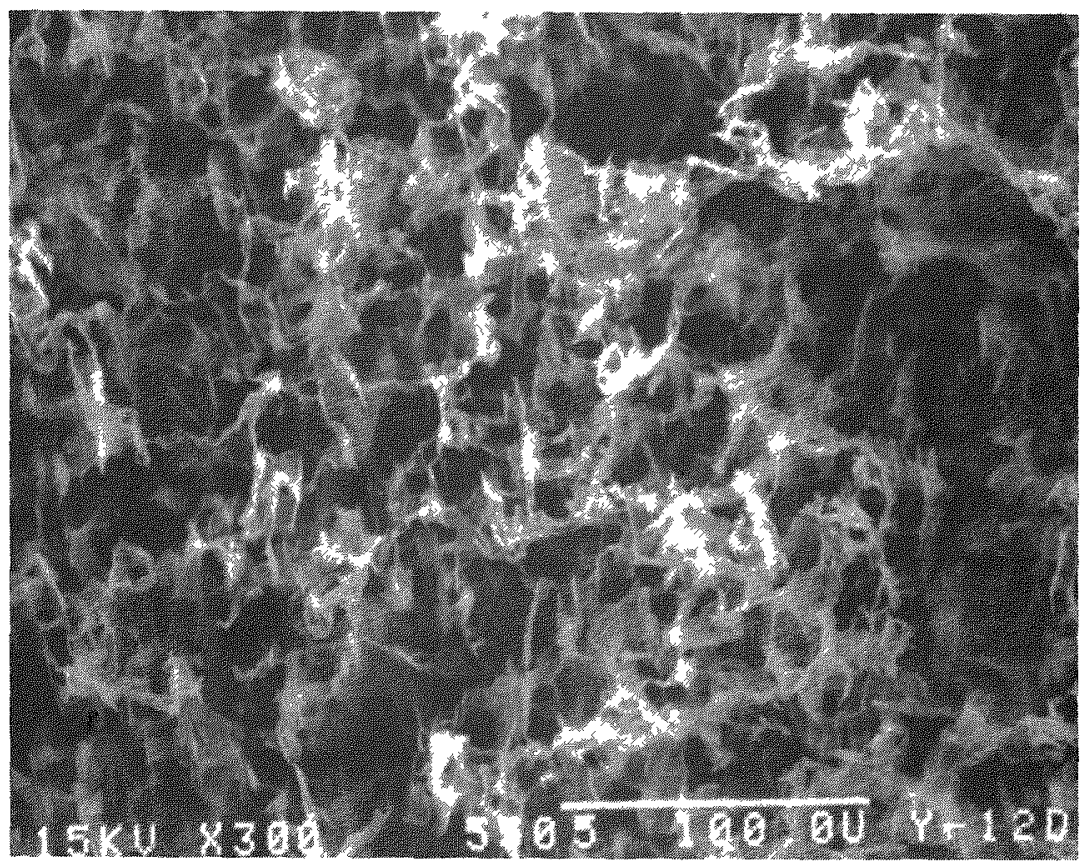

(b)

Fig. 23. SEM photomicrographs of a $6.7-\mathrm{mg} / \mathrm{cm}^{3}$ TPX $($ foam sample made with a 49/51 durene/naphthalene solvent eutectic, with the solvent removed by sublimation: (a) $100 \times$; (b) $300 \times$. 


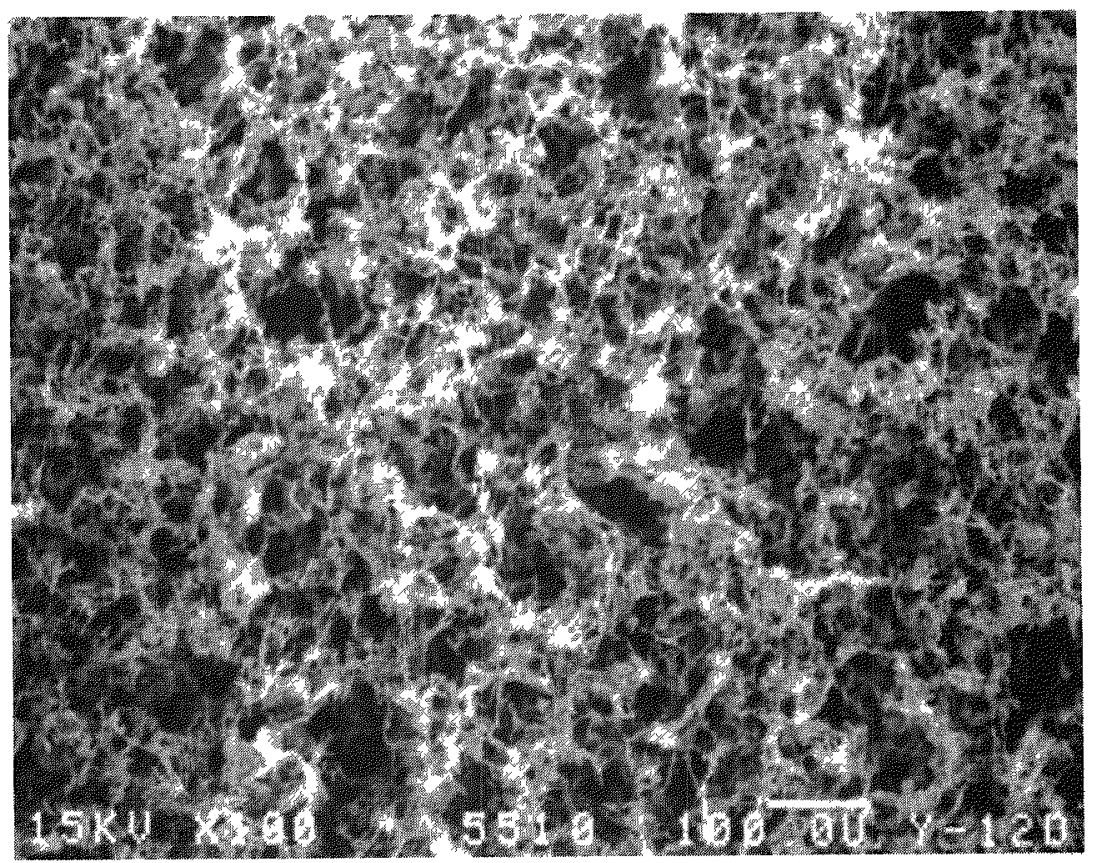

(a)

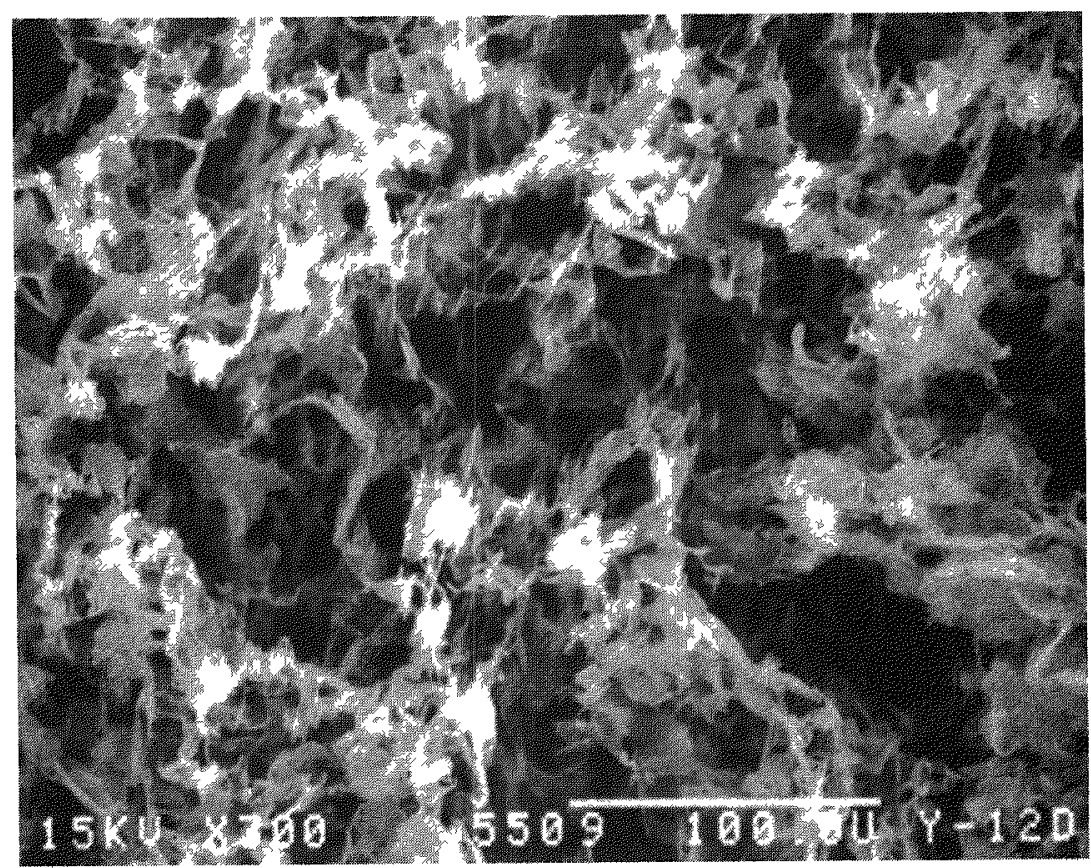

(b)

Fig. 24. SEM photomicrographs of a $5.1-\mathrm{mg} / \mathrm{cm}^{3}$ TPX $®$ foam sample made with a 49/51 durene/naphthalene solvent eutectic, with the solvent removed by sublimation: (a) $100 \times$; (b) $300 \times$ 


\section{HARDNESS OF TPX® FOAMS}

The firmness of TPX $®$ varied from very stiff to too soft to handle. For more quantitative data, the firmness or hardness of various densities of TPX ${ }^{\circledR}$ foams was measured with a Shore $\left({ }^{\circledR} 000\right.$ Durometer (trademark of the Shore Instrument and Manufacturing Co.). Shore 000 hardness is plotted as a function of foam density in Fig. 25. A hardness of 70 to 80 Shore 000 represents a very firm foam. Although the hardness does not track in a strict linear fashion with foam density, it can be loosely described by the equation $h=2.221 d+2.313$, where $h$ is the Shore 000 hardness and $d$ is the foam density.

Foams with densities above $20 \mathrm{mg} / \mathrm{cm}^{3}$ were moderately firm. Foams with densities between 10 and $20 \mathrm{mg} / \mathrm{cm}^{3}$ were fragile but could be handled without damage. Foams with densities below $6 \mathrm{mg} / \mathrm{cm}^{3}$ were very fragile and could not be handled without damage.

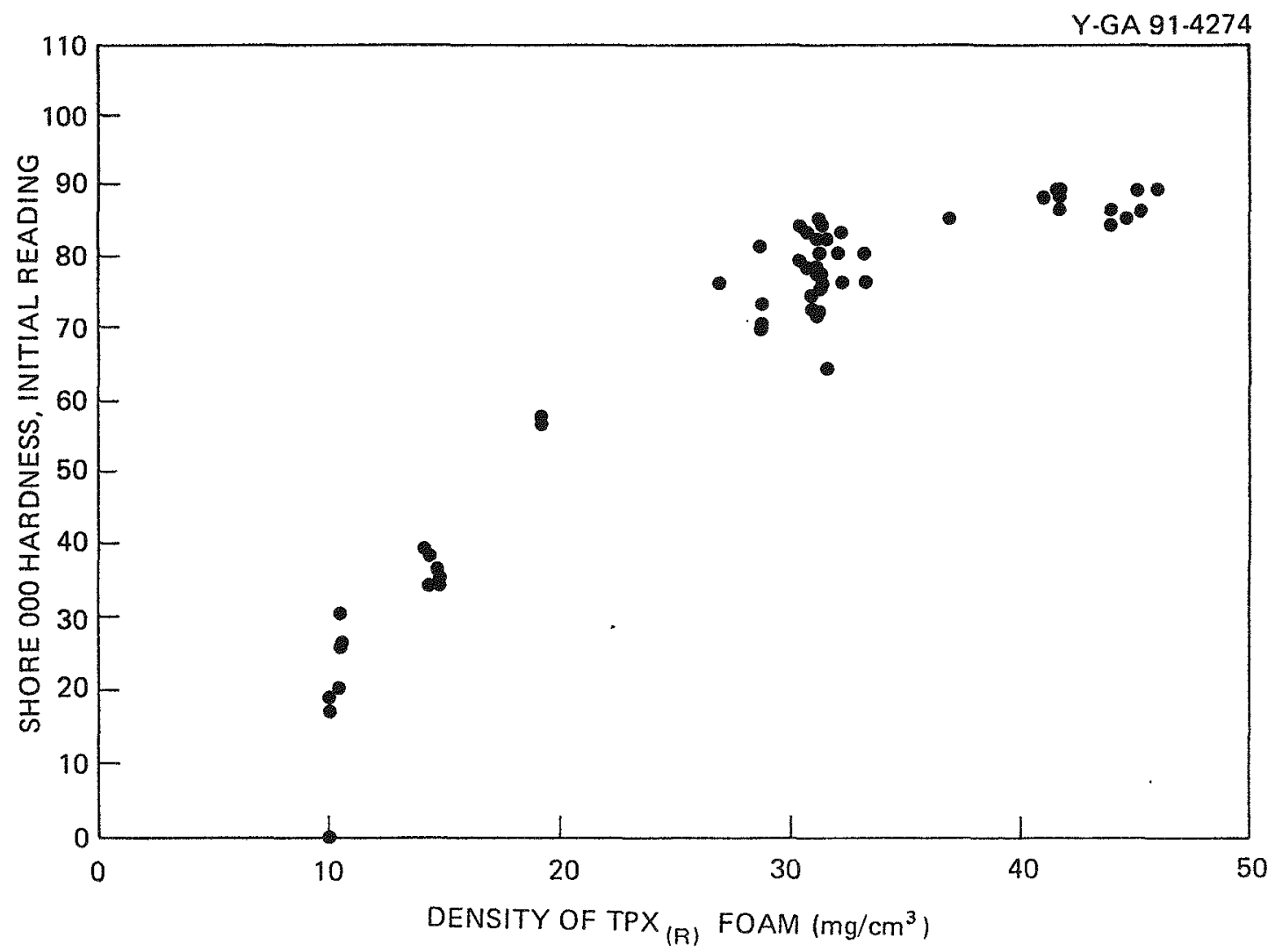

Fig. 25. Shore 000 Hardness as a function of TPX $®$ density. 


\section{CONCLUSIONS}

Well-interconnected, radiographically homogeneous poly(4-methyl-1-pentene), or TPX(B), foams were produced by phase inversion from a suitable solvent/ poor-solvent binary solvent system. In this study, 1,2,4,5-tetramethylbenzene, or durene, was used as the solvent, and naphthalene, tmpdo, and hexadecanol were used as poor solvents or nonsolvents. Homogeneity of the foam was found to be primarily dependent on the solvent-to-nonsolvent ratio and on the purity of the durene. Although the use of an inert gas cover during dissolving of the polymer had no effect on the efficiency of casting, it did provide for the ultimate in foam purity. Casting efficiency was found to be dependent on casting scheme, solvent-to-nonsolvent ratio, and quench temperature. Optimum casting efficiency for foam in the $30-\mathrm{mg} / \mathrm{cm}^{3}$ density range was obtained by dissolving TPX ${ }^{\circledR}$ in a 70/30 durene/naphthalene blend, casting in a heated Pyrex ${ }^{\circledR}$ tray, and quenching the resulting gel at $0^{\circ} \mathrm{C}$ under pressure. A second casting scheme that provided for gelation in a Teflon ${ }^{\circledR}$ cell and an oil bath, at a lower cooling rate during gelation, produced homogeneous foams with an efficiency $>60 \%$. In the Pyrex $($ trays, 60/40 durene/naphthalene blends produced tougher waxes that withstood thermal shock much better than did the $70 / 30$ blends.

In the density range of 5 to $55 \mathrm{mg} / \mathrm{cm}^{3}$, foam density tracked linearly with the polymer concentration of the durene/naphthalene or durene/tmpdo melt. Homogeneous, ultralow-density ( 5 to $6 \mathrm{mg} / \mathrm{cm}^{3}$ ) TPX ${ }^{\circledR}$ foams were produced using a $49 / 51$ durene/naphthalene eutectic solvent blend. Foam hardness or firmness tracked somewhat less linearly with foam density. Foams with densities greater than $20 \mathrm{mg} / \mathrm{cm}^{3}$ were firm. Foams with densities less than $6 \mathrm{mg} / \mathrm{cm}^{3}$ were too fragile to handle without damage. 


\section{ACKNOWLEDGMENTS}

The authors wish to acknowledge the assistance of J. D. Brown, V. S. Upchurch, Jr., and E. W. Stooksbury for producing the majority of the castings and for performing myriad tasks necessary to convert the castings into machined, characterized-foam samples. Acknowledgment is made of the machining assistance of B. J. Sutton and S. C. Robinson and of the assistance of S. C. Stinnette for statistical analysis of the data. 


\section{REFERENCES}

1. Alan K. Burnham, ed., Energy and Technology Review, UCRL-52000-89-10, Lawrence Livermore National Laboratory, October 1989, p. 12.

2. A. J. Castro, U.S. patent 4,247,498, January 27, 1981.

3. J. M. Williams and J. E. Moore, "Microcellular Foams: Phase Behavior of Poly (4-Methyl-1-Pentene) in Diisopropylbenzene," Polymer 28, 1950 (October 1987).

4. J. M. Williams and J. E. Moore, "Effect of Several Dual Solvents on the Phase Separation of Poly (4-Methyl-1-Pentene)," Polymer 30, 2279 (1989).

5. S. A. Letts, L. M. Lucht, R. J. Morgan, R. C. Cook, T. M. Tillotson, M. B. Mercer, and D. E. Miller, Progress in Development of Low Density Polymer Foams for the ICF Program, UCID-20537, Lawrence Livermore National Laboratory, June 1985.

6. M. R. Day, "TPX® Methylpentene Polymers," Plast. Polym., 101-8 (April 1968).

7. G. Charlet and G. Delmas, "Effect of Solvent on the Polymorphism of Poly (4-Methylpentene-1): 2. Crystallization in Semi-Dilute Solutions," Polymer 25, 1619 (November 1984).

8. R. W. Walker, "Method for Purifying Durene," U.S. patent 2,914,586, 1959.

9. D. E. Bown, "Recovery of Durene by Forming a Co-Crystallized Solid with Symmetrical Tetrachloroethane," U.S. patent 2,815,392, December 1957.

10. A. J. Shmidl, "Recovery and Purification of Durene," U.S. patent 2,560,373, 1948.

11. "Process for the Manufacture of Highly Knockproof, Low-Durene Gasoline," German Democratic Republic patent DD 254952 A1, 1986.

12. A. G. Duncan, "Dewaxing of a Hydrocarbon Feedstock by Direct Contact with a Refrigerant," U.S. patent 3,859,811, 1975.

13. V. Grinshpun and A. Rudin, "High Temperature GPC of Polyethylene," J. App. Polym. Sci. 30, 2413-18 (1985).

14. A. Rudin, "Molecular Weight Distributions of Polymers," J. Chem. Educ. 46, 595-600 (September 1969).

15. M. Pasternak and A. Morduchowitz, "Photochemical Oxidation and Dimerization of Alkybenzenes, Selective Reactions of the Alkyl Side Groups," Tetrahedron Lett. 24 (40), 4275-78 (1983).

16. T. Tangami, K. En, K. Yamaura, and S. Matsuzawa, "Gelation by Linking of Growing Spherulites in Poly(4-Methyl-1-Pentene)/Cyclohexane Solution," Polym. J. 18(1), 31-34 (1986). 


\section{APPENDIX A \\ IMPURITIES FOUND IN DURENE/NAPHTHALENE/TPX® AS A FUNCTION OF HEATING CONDITIONS}

\section{STATISTICAL EXPERIMENT}

Durene/naphthalene/TPX (B) melts exhibited varying amounts of discoloration when heated. The discoloration appeared to vary generally with temperature, time at temperature, air exposure at temperature as opposed to using an argon cover gas, purity of the starting durene, presence of naphthalene, and type of reaction vessel. Interestingly, certain lots of durene did not discolor, even when heated in air, and produced good-quality pmp foam. Other lots discolored rapidly when heated in air but still produced good foam. Durene/naphthalene/TPX® blends heated under an argon blanket did not discolor but produced foam of varying quality.

In order to better understand the melt chemistry and thereby ensure repeatability, as well as to satisfy academic curiosity, an experiment was designed to identify and quantify oxidation and degradation products. This experiment was statistically designed to give meaningful information about the relative amounts of impurities produced in durene/naphthalene/TPX® systems as a function of durene purity, presence of naphthalene, cover gas, and type of reaction vessel. Temperature and time at temperature were kept constant to simplify the experiment.

Heating in the presence of naphthalene was suspected of contributing to free-radical degradation because it is a polynuclear aromatic compound and as such is a hydrogen abstractor. Benzylic hydrogen atoms are easily abstracted, ${ }^{1}$ and durene has an abundance of these atoms. Naphthalene is also considered an initiator of photooxidative degradation. ${ }^{2}$

Heating in air was suspected of contributing to oxidation/degradation products. In fact, certain oxidation products, such as hydroperoxides and ketones resulting from processing polymers, are known to be strong initiators of photo-oxidative degradation. ${ }^{2}$ Pent-3-ene-2-one, for example, has been found as an impurity in pmp and can act as an initiator for photochemical degradation. $^{2}$

Including duplicates, a total of thirty-two 310-g samples were made. In each sample, 3.15 wt \% Mitsui RT18-grade TPX(B) was used. Two methods of durene purification were chosen for comparison: two-stage recrystallization in Freon $(B) 113$ and single-stage recrystallization in Freon ${ }^{\circledR} 113$ followed by distillation. The effect of the presence of naphthalene was tested by comparing samples prepared by dissolving polymer in durene alone and later adding naphthalene with samples prepared by dissolving the polymer directly in a $60 \mathrm{wt} \% / 40 \mathrm{wt} \%$ durene/ naphthalene blend. As for the effects of a cover gas, half of the samples were heated in argon, and the other half were heated in air.

Finally, to test for a potential catalytic degradation contribution of the container surface, heating was done in both Pyrex $($ and stainless steel beakers. All samples were heated for 205 min at a temperature ranging from 155 to $160^{\circ} \mathrm{C}$. 
RESULTS OF STATISTICAL EXPERIMENT

Results of the statistical experiment are shown in Fig. A.1. Impurity concentration is plotted as a function of treatment in this figure. The 16 treatments and duplicates were done randomly and have been grouped only for the purpose of presenting a more meaningful graph. The treatments are described in Table A.1.

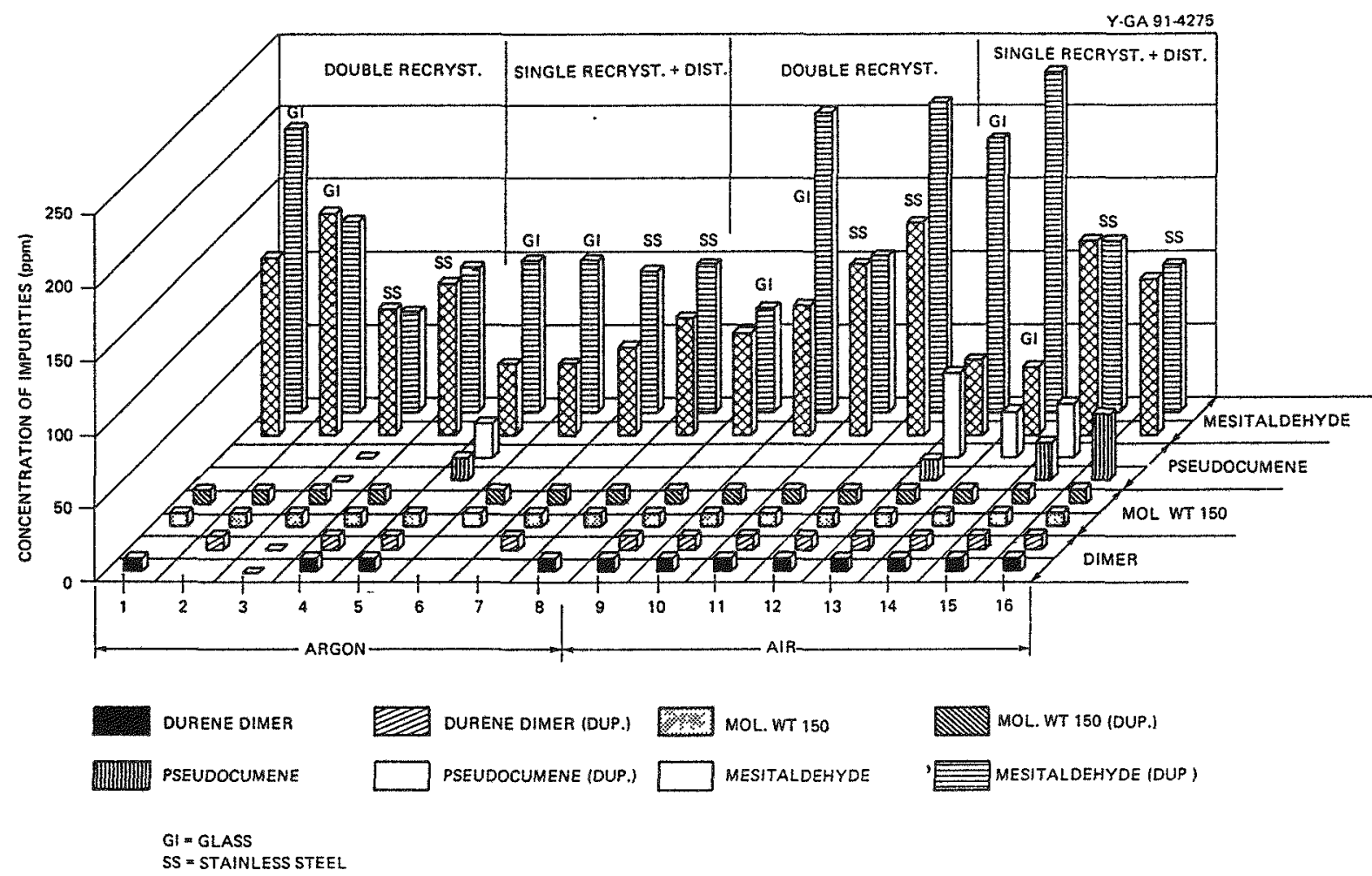

Fig. A.1. Impurity level as a function of heat treatment of durene, naphthalene, and TPX®. 
Table A.1. Description of heat treatments shown in Fig. A.1

\begin{tabular}{|c|c|c|c|c|c|c|}
\hline $\begin{array}{l}\text { Treatment } \\
\text { No. }\end{array}$ & $\begin{array}{l}\text { Sample } \\
\text { No. }\end{array}$ & $\begin{array}{c}\text { Method of } \\
\text { durene purification }\end{array}$ & $\begin{array}{l}\text { Content } \\
\text { of melt }\end{array}$ & $\begin{array}{c}\text { Container } \\
\text { type }^{\mathrm{b}}\end{array}$ & $\begin{array}{l}\text { Cover } \\
\text { gas }\end{array}$ & $\begin{array}{l}\text { Color } \\
\text { after } \\
\text { heating }\end{array}$ \\
\hline 1 & 25,31 & Double recryst. $^{c}$ & $\mathrm{D}+\mathrm{P}$ & Glass & Argon & $\begin{array}{l}\text { Colorless to } \\
\text { pale yellow }\end{array}$ \\
\hline 2 & 13,23 & Double recryst. & $\mathrm{D}+\mathrm{N}+\mathrm{P}$ & Glass & Argon & Colorless \\
\hline 3 & 8,10 & Double recryst. & $D+P$ & SS & Argon & Colorless \\
\hline 4 & 14,22 & Double recryst. & $\mathrm{D}+\mathrm{N}+\mathrm{P}$ & SS & Argon & Colorless \\
\hline 5 & 15,27 & Single recryst. + dist. $^{d}$ & $D+P$ & Glass & Argon & Colorless \\
\hline 6 & 11,29 & Single recryst. + dist. & $\mathrm{D}+\mathrm{N}+\mathrm{P}$ & Glass & Argon & Colorless \\
\hline 7 & 12,24 & Single recryst. + dist. & $D+P$ & SS & Argon & Colorless \\
\hline 8 & 4,28 & Single recryst. + dist. & $\mathrm{D}+\mathrm{N}+\mathrm{P}$ & SS & Argon & Colorless \\
\hline 9 & 1,5 & Double recryst. & $\mathrm{D}+\mathrm{P}$ & Glass & Air & Orange \\
\hline 10 & 3,21 & Double recryst. & $D+N+P$ & Glass & Air & $\begin{array}{l}\text { Yellowish } \\
\text { orange }\end{array}$ \\
\hline 11 & 2,20 & Double recryst. & $\mathrm{D}+\mathrm{P}$ & ss & Air & Orange \\
\hline 12 & 26,30 & Double recryst. & $\mathrm{D}+\mathrm{N}+\mathrm{P}$ & SS & Air & Orange \\
\hline 13 & 7,19 & Single recryst. + dist. & $\mathrm{D}+\mathrm{P}$ & Glass & Air & Orange \\
\hline 14 & 9,17 & Single recryst. + dist. & $\mathrm{D}+\mathrm{P}+\mathrm{N}$ & Glass & Air & Tan \\
\hline 15 & 16,18 & Single recryst. + dist. & $\mathrm{D}+\mathrm{P}$ & ss & Air & Orange \\
\hline 16 & 6,32 & Single recryst. + dist. & $\mathrm{D}+\mathrm{N}+\mathrm{P}$ & SS & Air & Tan \\
\hline
\end{tabular}

${ }^{2} \mathrm{D}=$ Durene; $\mathrm{N}=$ Naphthalene; $\mathrm{P}=$ polymer.

${ }^{\mathrm{b}} \mathrm{SS}=$ stainless steel beaker.

${ }^{c}$ Double recrystallization (recrystallized from Freon 113 in two stages).

${ }^{d}$ Single recrystallization plus distillation (recrystallized from Freon ${ }^{\circledR} 113$ in one stage and then distilled).

Figure A. 1 is organized along the $\mathrm{x}$-axis in two major groupings: argon cover gas and air cover gas. Each of these two groups is further broken down along the $\mathrm{x}$-axis according to methods of durene purification: two-stage recrystallization from Freon( ${ }^{\circledR} 113$ and single recrystallization followed by distillation. Duplicate runs are shown along the $\mathrm{z}$-axis along with the four main impurities: pseudocumene, mesitaldehyde, durene dimer, and mol. wt 150 species. The results, grouped according to impurity, are as follows:

Pseudocumene:

At the 95\% confidence level, statistically less liquid pseudocumene was found for durene purified by two-stage recrystallization than for durene purified by single-stage crystallization followed by distillation. A significant durene/cover gas interaction was found. Recrystallized/distrilled durene heated in air produced significantly worse results than did the other three combinations. No other interactions or factors were found to be statistically significant. 
Mesitaldehyde:

Mesitaldehyde was expected to be a product of oxidation of durene. However, because of the scatter in the data, no factors or interactions were found to be statistically significant for mesitaldehyde.

Durene Dimer:

Although durene dimers were found in trace amounts, samples heated under an argon cover produced durene dimer significantly less often than did samples heated in air. This impurity often was found concentrated on the foam after solvent removal.

Mol. Wt 150 Species:

No factors or interactions were found to be statistically significant for the formation of the mol. wt 150 species. This species was found in only trace amounts that later concentrated on the foam during solvent removal.

In summary, melts produced statistically lower concentrations of impurities when doubly recrystallized durene and an argon cover gas were employed. Neither the container type nor the presence or absence of naphthalene affected the results significantly.

\section{EXTRACTION OF IMPURITIES FROM TPX® FOAMS}

To carry the experiment one more step, several samples of pmp foam were chosen for further scrutiny, Radiographically homogeneous, white pmp foams formed by heating under argon and sometimes in air, as well as radiographically inhomogeneous, badly discolored foams formed in air, were further analyzed. Both types of foam were extracted in Freon ${ }^{\circledR} 113$ and analyzed by GC-MS. Comparatively high levels of oxidation and decomposition products were found in the extract of the discolored foam. These included $\mathrm{C}_{15}, \mathrm{C}_{16}$, and $\mathrm{C}_{17}$ polymer fragments, four isomers of durene dimers, an unidentified mol. wt 150 species, and smaller amounts of pseudocumene. These data suggest that a considerable amount of free-radical and perhaps peroxidation activity had occurred while the melt was heating in air. ${ }^{3}$ [TPX $(B)$ polymer is known to be graft copolymerized with straight-chain polyolefin to reduce the crystallinity of the polymer.] In contrast to this, Freon ${ }^{\circledR} 113$ extracts of white, homogeneous pmp foams that were formed by heating either in argon or (sometimes) in air showed lower levels of only the $\mathrm{C}_{15}$ polymer fragments, only one isomer of durene dimers, no pseudocumene, and no mol. wt 150 species. Those data suggest less free-radical or peroxidation activity during heating under argon and in certain cases in air. Figure A.2 illustrates the impurity data for this phase of the TPX® study.

Catalytic activity generated by trace quantities of materials below the detection levels of our analytical instrumentation may explain the differences observed for samples heated in air. 


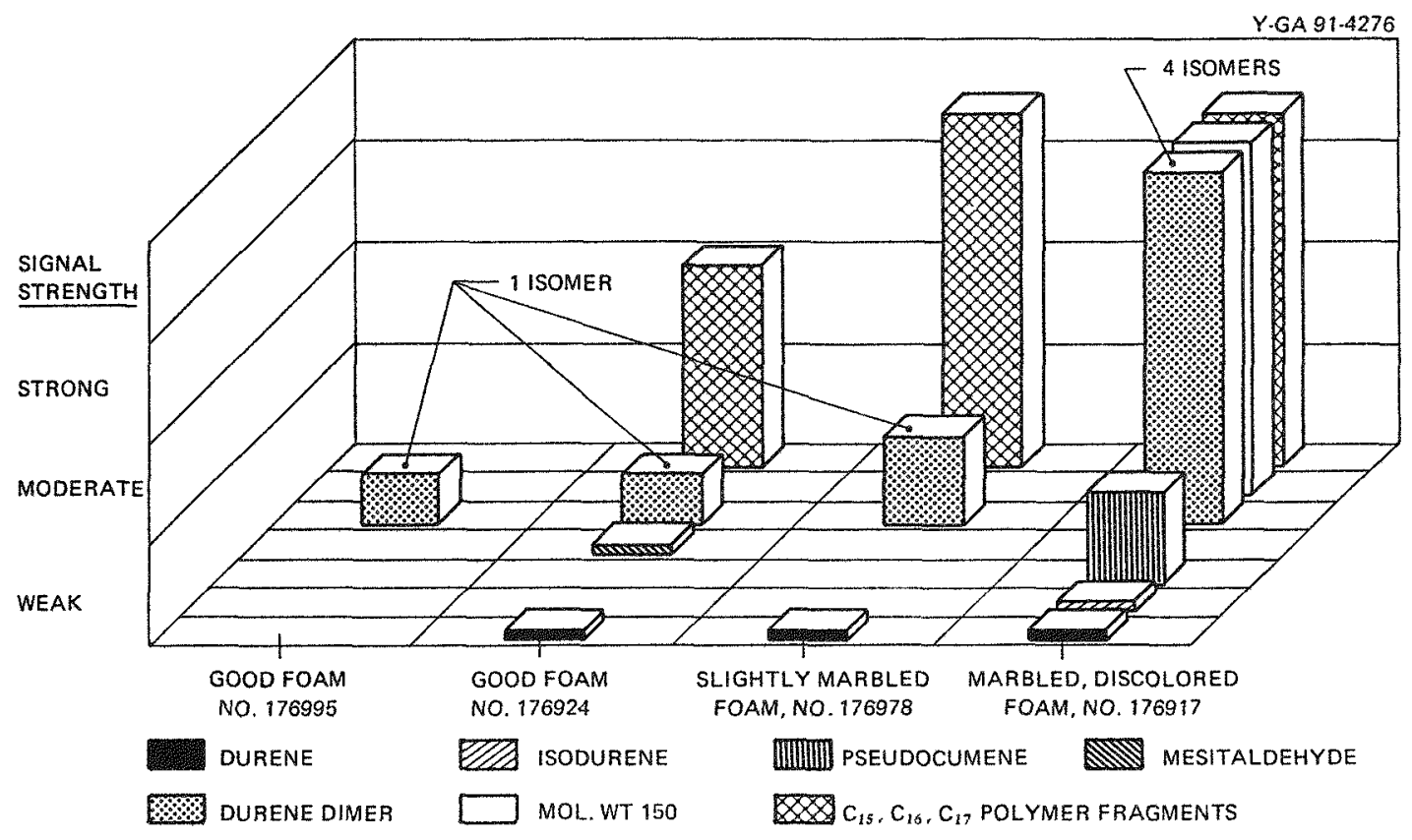

Fig. A.2. Impurities for various qualities of TPX® foam.

\section{REFERENCES}

1. R. T. Morrison and R. N. Boyd, Organic Chemistry, Second Edition, Allyn and Bacon, Inc., Boston, 1966.

2. D. J. Carlsson, K. H. Chan, A. Garton, and D. M. Wiles, "Photo-Oxidation Degradation of Polypropylene and Stabilization by Hindered Amines," Pure Appl. Chem. 52, 389-98 (1980).

3. W. Schnabel, Polymer Degradation, Principles and Applications, Hanser International, New York, 1981. 


\section{APPENDIX B \\ OTHER INTERESTING FOAM MORPHOLOGIES}

Small fractions of the pmp polymer were replaced with various other polymers to determine the effect of such a replacement on foam morphology and physical properties. Foam morphology changed very little when up to $10 \mathrm{wt} \%$ quantities of pmp were replaced with poly(2,6-dimethyl-p-phenylene oxide), various molecular weights of polyethylene, paraffin wax, and polyethylene/acrylic acid copolymer (10 wt \% acrylic acid content). When $6,000,000-\mathrm{mol}$. wt $\%$ polyisobutylene was added in an amount that represented $10 \mathrm{wt} \%$ of the polymer content, radiographic uniformity did not suffer. Foam morphology, on the other hand, did change in the sense that a secondary "pock" structure was found imposed on the typical open-celled foam morphology. This is shown in Fig. B.1. Foam samples with up to $20 \mathrm{wt} \%$ of the polyisobutylene did not become flexible but remained rather stiff. 


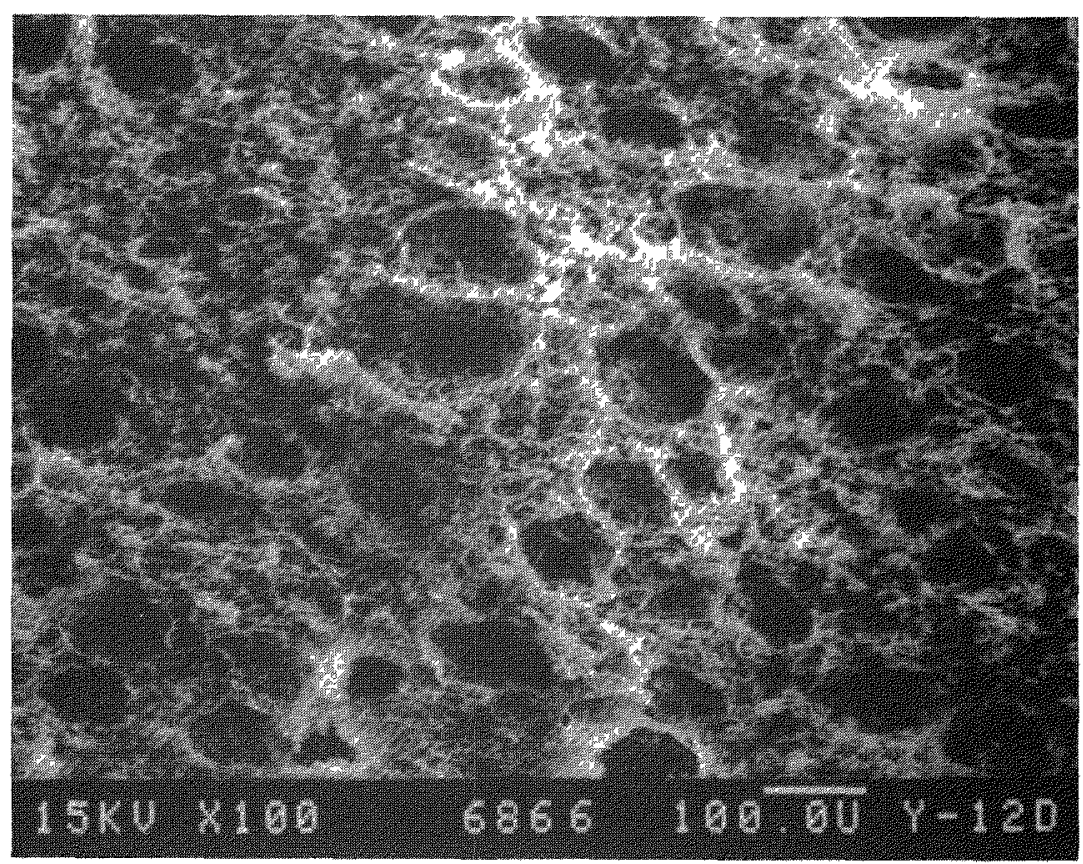

(a)

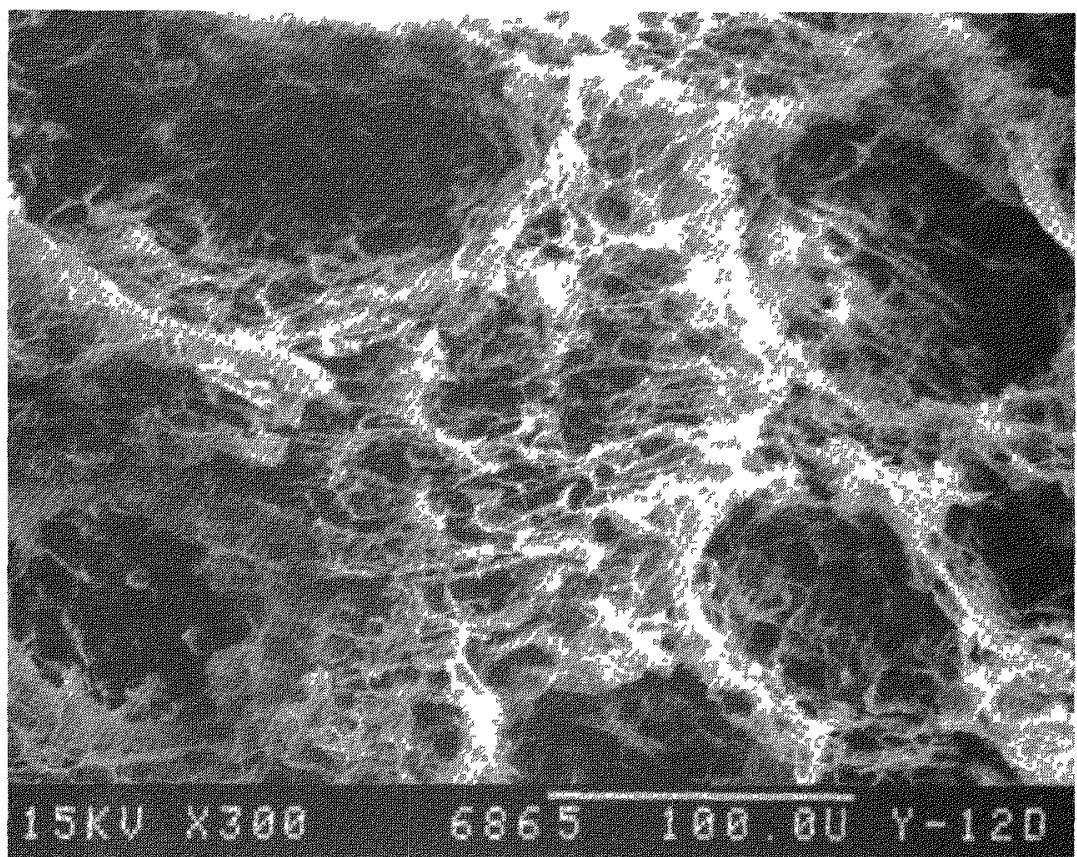

(b)

Fig. B.1. SEM photomicrographs of $52-\mathrm{mg} / \mathrm{cm}^{3}$ TPX $(10 \mathrm{wt} \%$ polyisobutylene foam sample made with a $60 / 40$ durene/naphthalene solvent blend, with the solvent removed by sublimination: (a) 100x; (b) 300x. 


\section{DISTRIBUTION}

\section{Allied-Signal Kansas City}

Baker, G. Keith

Guttridge, Aysun

Smith, H. M.

EG\&G Mound Facility

Glascow, G.

Trainer, $\mathrm{P}$.

Lawrence Livermore National Laboratory

Galles, Harry

Kolb, John

Pekala, Rick

Los Alamos National Laboratory

Williams, J, M.

Oak Ridge Y-12 Plant

Babb, W. D.

Bolinger, W. L.

Burditt, R. B.

Clift, J. $\mathbf{H}$.

Churnetski, E. L.

Davis, W. E.

Day, J. R.

Dorsey, G. F.

Dorsey, J. G.

Edwards, C. C.

Googin, J. M.

Johnson, C. E.

Lee, A. K. (2)

Northcutt, W. G./Campbell, V. B.

Robinson, D. N.

Simandl, R. F. (10)

Thompson, L. M.

Thrasher, T, T.

Y-12 Plant Records (RC)

Sandia National Laboratories - Albuquerque

Aubert, J. H.

Lagasse, R. R.

Sylwester, Alan

West, L. A. 
Sandia National Laboratories - Livermore

Even, Bill

Wang, J. C. F.

Given distribution as shown in DOE/OSTI-4500, under UC-704, Materials (106 copies). 